\title{
29. THE COMPRESSIONAL-WAVE VELOCITY OF AMAZON FAN SEDIMENTS: CALCULATION FROM INDEX PROPERTIES AND VARIATION WITH CLAY CONTENT ${ }^{1}$
}

\author{
Roger D. Flood, ${ }^{2}$ Carlos Pirmez, ${ }^{3}$ and Hezhu Yin ${ }^{4}$
}

\begin{abstract}
Acoustic properties of unconsolidated marine sediments contain important information about sedimentary materials, and velocity structure is important for relating time on seismic profiles to depth in the sediments. We have analyzed the velocity structure of the Leg 155 Amazon Fan sediments from two independent perspectives. In situ compressional-wave velocities were calculated following the Biot model for sediment acoustic properties from shipboard measurements of porosity and grain density. Some of the parameters for this calculation were derived from the comparison of calculated velocities with those determined from wireline logs and applied to other sites. This approach suggests that surficial sediment deposits are normally consolidated, but that debris-flow deposits and some buried levees are overconsolidated. We also identified some buried levees where underconsolidated sediments directly underlie the debris-flow deposits. The velocity-depth information was used to determine a time-depth curve at each site. The curves are similar above 200 meters below seafloor, but diverge at greater depths. Sediment depths for deeper layers determined aboard Leg 155 are 10-20 m less than initially determined. An analysis of the relationships between compressional-wave velocity and clay volume and between porosity and clay volume suggests that clay minerals and framework grains bear the overburden stress in surficial levees and sand units (a matrix-supported structure or isostress condition). Framework grains bear the overburden stress in deeper levees and debris-flow (a grain-supported structure or isostrain condition). These observations are all consistent with the upper $400 \mathrm{~m}$ of the Amazon Fan being uncemented and unlithified, except for some restricted zones where iron sulfides (e.g., hydrotroilite) or gas hydrates may affect the sediment acoustic properties.
\end{abstract}

\section{INTRODUCTION}

Compressional-wave velocity is a primary sediment characteristic that provides important information about the mechanical properties of those sediments that may be difficult to determine otherwise. The correlation of cored sequences to seismic profiles also requires a knowledge of the vertical compressional-wave velocity structure. Seismic velocity information for continental margin settings traditionally comes from the analysis of sonobuoy data and multichannel seismic data. When holes are drilled in a region, additional information on sediment velocity can come from logging or other downhole experiments, from velocity measurement on recovered sediment, or through velocity calculation from index properties (e.g., density). Log information can also be used to generate synthetic seismograms for more detailed core-seismic correlation. Acoustic properties of unconsolidated sediments are sensitive to the mechanical properties of the sediments as well as to sediment lithology, thus a detailed understanding of the acoustic properties of fan sediments may provide important insights into the structure and processes active on the fan.

During Ocean Drilling Program (ODP) Leg 155, 17 sites were drilled on the Amazon Fan to study fan growth patterns, fan depositional processes, and equatorial paleoclimate. Much of our understanding of the structure of the Amazon Fan comes from interpretation of seismic profiles, thus correlating seismic records to drill sites is a high priority. Prior to Leg 155, compressional-wave velocity information on the Amazon Fan came from regional sonobuoy studies (Houtz, 1977; Shipboard Scientific Party, 1995a). During Leg 155, wireline logs measured in situ compressional-wave velocity on por-

${ }^{1}$ Flood, R.D., Piper, D.J.W., Klaus, A., and Peterson, L.C. (Eds.), 1997. Proc. ODP, Sci. Results, 155: College Station, TX (Ocean Drilling Program).

${ }^{2}$ Marine Sciences Research Center, State University of New York, Stony Brook, NY 11794-5000, U.S.A.rflood@ sunsyb.edu

${ }^{3}$ Borehole Research Group, Lamont-Doherty Earth Observatory, Palisades, NY 10964, U.S.A.

${ }^{4}$ Exxon Production Research Company, P.O. Box 2189, Houston, TX 77252-2189, U.S.A. tions of seven of the sites occupied. For sites and depth intervals that were not logged, an alternate approach is needed to estimate in situ compressional-wave velocity from routine laboratory measurements. Although velocity can often be measured in the laboratory on cored sediments, most of the sediment recovered from the Amazon Fan during Leg 155 was gassy, and few laboratory velocity measurements could be made. As a result, we need to use an approach that will estimate in situ compressional-wave velocity from sediment index properties that were measured aboard ship to make more accurate time-depth calculations.

Two methods have been used to estimate sediment compressional-wave velocity from measured sediment properties. Hamilton (1980 and references therein) developed an approach based on existing velocity measurements to predict acoustic properties in regions where few measurements are available. Stoll (1989) describes the Biot theory applied to sediment acoustic properties and an approach for calculating acoustic properties from sediment properties such as porosity, grain size, permeability, and effective stress; however, this approach also requires that a number of other sediment properties be realistically estimated. This study reports an initial attempt to use the predictive approach described by Stoll (1989) to determine sediment compressional-wave velocity from measured index properties. This information is then used to determine the time-depth relationship at sites drilled on the Amazon Fan and to provide independent evidence on the mechanical properties of Amazon Fan sediments.

Information on the mechanical state of sediments in situ can also be determined through evaluating the relationships between sediment parameters such as velocity, porosity, and the amount of clay present in a sample. The effects of composition and acoustic response in clastic sedimentary rocks has long been a topic of interest to both hydrocarbon exploration and academic research. Several researchers have focused on the relationship between porosity and acoustic velocity (e.g., Wyllie et al., 1956; Hamilton and Bachman, 1982; Jarrard et al., 1989; Jarrard et al., 1993; Carlson et al., 1986) and its implications for predicting vertical variations of acoustic velocity and changes in lithologic composition. However, the models resulting from porosi- 
ty-velocity relations are difficult to apply as predictive tools because the curves cannot, in general, be extended to different localities. Yin (1993) suggested that the relationship between porosity and velocity is discontinuous at a critical porosity value of $\sim 30 \%-40 \%$ (dependent on the lithology; Yin, 1993; Yin et al., 1993). At porosities above critical, the structure is matrix supported as both the framework and matrix (and perhaps the fluid) phases bear the stresses applied on the rock, whereas at porosities below than the critical value, the structure is grain supported as only the framework grains bear the stress. Sediments with different depositional histories thus may have different relationships between velocity and porosity, depending on the lithology of the sediment. The Amazon Fan is a good place to test these relationships because the part sampled is thick and largely uncemented. We may be able to observe acoustic trends that might otherwise be masked by lithification.

Here we examine the relationships between porosity, compressional-wave velocity, and clay content in different lithologic settings using logging data. The characteristics of the relationships between porosity and velocity vs. clay content should provide information on the physical structure of Amazon Fan sediments. Furthermore, by examining the properties of different stratigraphic and sedimentary units, it may be possible to determine how these properties change through time and with the various sedimentary processes at work on the fan. Understanding how these relationships vary within different sedimentary units may be used as a predictive tool to determine the elastic modulii (bulk and shear modulii) as a function of the clay content and thus calculate how acoustic velocity varies within the fan (Yin, 1993; Yin et al., 1993).

\section{METHODS}

\section{Compressional-Wave Velocity Calculation}

Compressional-wave velocity profiles were calculated for each of the Leg 155 sites using the approach outlined by Stoll (1989) based on the Biot acoustic model for sediments. Sub-bottom depths (meters below seafloor; mbsf) used for sediment samples are those reported aboard ship and are uncorrected for gas expansion, voids, or partial recovery. Calculated compressional-wave velocities were compared with compressional-wave velocities measured in the logged holes by the long-spaced sonic tool (LSS; Shipboard Scientific Party, 1995a).

The logging data used in this study were processed post cruise by the Borehole Research Group (BRG) at Lamont-Doherty Earth Observatory and published in the site chapters and on the CD-ROM included in Flood, Piper, Klaus, et al., 1995. The velocities measured using the longer source-receiver path pairs (i.e., 10 and $12 \mathrm{ft}$, or 3.05 and $3.66 \mathrm{~m}$ ) are used in this study. Sub-bottom log depths have been corrected by the BRG to account for wire slippage and to agree with other logs; however, especially in cases of partial core recovery, subbottom depths determined for core samples may not agree with those determined for log measurements because standard ODP procedure is to assume the sediment came from the top of the cored interval. For the purposes of this analysis, reported sub-bottom depths are assumed to be correct for both discrete sample and log data.

Calculating acoustic properties using the Biot approach requires the knowledge of a number of parameters that describe fluid and sediment properties (Table 1). Some of the required parameters can be derived by calculation from temperature and depth, some by direct measurement on the cores, some by reference to the literature, and some by less direct methods based on laboratory and field experiments (Stoll, 1989). The Biot model also determines shear-wave velocity and attenuation as well as compressional-wave velocity and attenuation; however, here we only describe the results of the compressional-wave velocity calculations. Our calculations are for a frequency of $100 \mathrm{~Hz}$ (typical of our air gun records).

Compressional-wave velocity was calculated at depths where index properties measurements (in particular void ratio, or porosity, and grain density) were made aboard ship, and the values used here are those reported in the site chapters and on the CD-ROM included in Flood, Piper, Klaus, et al. (1995). The index properties data were

Table 1. Source of information used in the compressional-wave velocity calculations.

\begin{tabular}{|c|c|c|c|c|c|c|c|c|c|}
\hline \multicolumn{2}{|c|}{ Fluid properties } & \multicolumn{2}{|c|}{ Measured sediment properties } & \multicolumn{2}{|c|}{$\begin{array}{l}\text { Properties determined from } \\
\text { sediment classification }\end{array}$} & \multicolumn{2}{|c|}{$\begin{array}{l}\text { Properties related to sediment } \\
\text { classification and burial }\end{array}$} & \multicolumn{2}{|c|}{ Other model parameters } \\
\hline Property & Source & Property & Source & Property & Source & Property & Source & Property & Source \\
\hline $\begin{array}{l}\text { Fluid bulk } \\
\text { modulus }\end{array}$ & $\begin{array}{l}\text { Calculated from } \\
\text { temperature } \\
\text { and pressure }\end{array}$ & Void ratio & $\begin{array}{l}\text { Measured index } \\
\text { property }\end{array}$ & Pore radius & $\begin{array}{l}\text { From estimated } \\
\text { mean size } \\
(\text { mean size/6.5) }\end{array}$ & Permeability & $\begin{array}{l}\text { Bryant et al. (1975) } \\
\text { relationships for } \\
\text { Gulf of Mexico }\end{array}$ & $\begin{array}{l}\text { Structure } \\
\text { factor for } \\
\text { capillaries }\end{array}$ & $\begin{array}{l}1.25 \text { for natural } \\
\text { particulate } \\
\text { sediments }\end{array}$ \\
\hline $\begin{array}{l}\text { Fluid } \\
\text { density }\end{array}$ & $\begin{array}{l}\text { Calculated from } \\
\text { temperature } \\
\text { and pressure }\end{array}$ & $\begin{array}{l}\text { Grain } \\
\text { density }\end{array}$ & $\begin{array}{l}\text { Measured index } \\
\text { property }\end{array}$ & $\begin{array}{l}\log \\
\quad \text { decrement }\end{array}$ & $\begin{array}{l}0.1 \text { for silts and } \\
\text { clays, } 0.05 \\
\text { for sands }\end{array}$ & $\begin{array}{l}\text { Overburden } \\
\text { (vertical) } \\
\text { stress }\end{array}$ & $\begin{array}{l}\text { Integrate bouyant- } \\
\text { weight profile }\end{array}$ & $\begin{array}{l}\text { Poisson's } \\
\text { ratio of } \\
\text { frame }\end{array}$ & Constant, 0.1 \\
\hline \multirow[t]{3}{*}{$\begin{array}{l}\text { Fluid } \\
\text { viscosity }\end{array}$} & $\begin{array}{l}\text { Constant }(0.01 \\
\left.\text { dynes } / \mathrm{cm}^{2}\right)\end{array}$ & & & & & $\begin{array}{l}K_{0}(\text { ratio of } \\
\text { horizontal } \\
\text { to vertical } \\
\text { stress })\end{array}$ & $\begin{array}{l}\text { Used to relate } \\
\text { overburden to } \\
\text { effective stress } \\
0.7 \text { for normally } \\
\text { consolidated near- } \\
\text { surface levee } \\
\text { deposits and sandy } \\
\text { units }\end{array}$ & $\begin{array}{l}\text { Bulk } \\
\text { modulus } \\
\text { of frame }\end{array}$ & $\begin{array}{l}\text { Determine from } \\
\text { complex shear } \\
\text { modulus using } \\
\text { ratio of Young's } \\
\text { modulus } \\
\text { decrement to log } \\
\text { decrement } \\
\text { (constant, 1.3) }\end{array}$ \\
\hline & & & & & & & $\begin{array}{l}1-2.25 \text { for } \\
\text { overconsolidated } \\
\text { deep debris-flow } \\
\text { deposits } \\
0.1-0.2 \text { for } \\
\text { underconsolidated } \\
\text { buried levees } \\
0.7-1.5 \text { for } \\
\text { normally or } \\
\text { overconsolidated } \\
\text { buried levees }\end{array}$ & & \\
\hline & & & & & & $\begin{array}{l}\text { Shear } \\
\text { modulus }\end{array}$ & $\begin{array}{l}\text { Calculated from } \\
\text { effective stress } \\
\text { and void ratio } \\
\text { based on Bryan } \\
\text { and Stoll, } 1988, \\
\text { using } F F=2.25\end{array}$ & & \\
\hline
\end{tabular}


edited to remove samples where anomalous void ratios were reported. Anomalously low void ratios may have resulted from the draining of water into or out of nearby coarser layers. Anomalously high void ratios may have resulted from sediment disturbance during coring. For this study, anomalous void ratios were identified on the basis of their falling off the overall downcore trend. Although a more rigorous evaluation might have retained some of the discarded data, it would not have changed the overall results of this study because only $\sim 7 \%$ of the samples were marked as bad. However, no effort was made in this study to integrate calculated and log results, to estimate properties of sediment sections where no samples were recovered, or to characterize sediment layers (especially sands) that were usually avoided for physical properties measurements.

Compressional-wave velocity was calculated for each sample depth by the following overall procedure. The calculations were done using a BASIC computer program "AMAVELCP" that was based in part on the programs "GEOMOD3" and "BIOT91" provided by R.D. Stoll (R.D. Stoll, pers. comm., 1991). The results of these calculations are provided in Table 2 on CD-ROM in the back pocket of this volume.

1. For each sample, the total depth and in situ temperature were determined from the water depth, sub-bottom depth, and the temperature gradient measured at the site. Water properties, including compressional-wave velocity, density, and bulk modulus were calculated assuming a constant salinity of 35 parts per thousand.

2. The index-properties samples are coded in the sediment categories of Bryant et al. (1975) because their permeability equations were used in a later step. They grouped Gulf of Mexico sediments in four categories: Category 1 for sediments with more than $80 \%$ clay, Category 2 for sediments with $60 \%-80 \%$ clay, Category 3 for sediments with less than $5 \%$ sand and less than $60 \%$ clay, and Category 4 for sediments with more than $5 \%$ sand. Leg 155 samples were put into one of these categories based on visual core descriptions. In general, levee sediments were assigned to Category 3 ( $88 \%$ of the samples), debris-flow and pelagic sediments were assigned to Category 2 (7\% of the samples), and channel and other sands were assigned to Category 4 ( $5 \%$ of the samples). Mean sediment sizes were taken as $4,8,30$, and $45 \mu \mathrm{m}$ for Categories 1-4, respectively. Following Stoll (1989), the size of the mean pore radius is taken as the mean sediment size divided by 6.5 .

3. Sediment bulk density was calculated from measured void ratio (or porosity) and grain density and from calculated water density. Sediments recovered by the extended core barrel (XCB) generally had void ratios that were $\sim 5 \%$ higher than those recovered by the advanced piston corer (APC; e.g., Shipboard Scientific Party, 1995f), perhaps because the XCB is drilled into the sediment, whereas the APC is pushed into the sediment like a piston core. The void ratios measured in XCB core sections were reduced to $95 \%$ of their measured values to provide a consistent measure of the void ratio downcore. Many individual XCB cores showed variations in porosity down core apparently caused by the coring process (e.g., Shipboard Scientific Party, 1995d). No attempt was made to apply a correction to these data. Measured grain densities range from 2.568 to 3.064 , with an average of 2.74 . Seventy-eight percent of the grain-density measurements fell between 2.7 and 2.8 .

4. The buoyant unit weight of the overlying sediment column was integrated to determine the overburden pressure. The effective horizontal stress was calculated from the overburden pressure, or vertical stress through the ratio of horizontal to vertical stress $\left(K_{0}\right.$, also known as the coefficient of earth pressure at rest; Stoll, 1989). The effective stress is the average of the vertical stress and the two horizontal stresses (assumed equal), and can be calculated as $\left(1 / 3+2 \cdot K_{0} / 3\right)$ times the overburden pressure. If $K_{0}=1$, then the horizontal and vertical
Table 3. Summary of $K_{0}$ values used in calculating compressional-wave velocity.

\begin{tabular}{|c|c|c|c|c|c|}
\hline Site & $\begin{array}{l}\text { Top } \\
\text { (mbsf) }\end{array}$ & $\begin{array}{l}\text { Bottom } \\
\text { (mbsf) }\end{array}$ & $K_{0}$ & Generalized facies & $\begin{array}{l}\text { Velocity log } \\
\text { availability }\end{array}$ \\
\hline 930 & $\begin{array}{r}0 \\
187\end{array}$ & $\begin{array}{l}186 \\
242\end{array}$ & $\begin{array}{l}0.70 \\
1.50\end{array}$ & $\begin{array}{l}\text { Levee } \\
\text { Debris-flow deposit }\end{array}$ & $\begin{array}{l}\text { Not available } \\
\text { Not available }\end{array}$ \\
\hline 931 & $\begin{array}{r}0 \\
162 \\
349 \\
359\end{array}$ & $\begin{array}{l}136 \\
348 \\
358 \\
412\end{array}$ & $\begin{array}{l}0.70 \\
2.00 \\
0.70 \\
1.50\end{array}$ & $\begin{array}{l}\text { Levee } \\
\text { Debris-flow deposit } \\
\text { Top of deep levee } \\
\text { Deep levee }\end{array}$ & $\begin{array}{l}\text { Bottom of interval } \\
\text { Top of interval } \\
\text { Not available } \\
\text { Not available }\end{array}$ \\
\hline 932 & 0 & 167 & 0.70 & Levee & Not available \\
\hline 933 & $\begin{array}{r}0 \\
101 \\
167\end{array}$ & $\begin{array}{l}100 \\
161 \\
249\end{array}$ & $\begin{array}{l}0.70 \\
1.75 \\
1.50\end{array}$ & $\begin{array}{l}\text { Levee } \\
\text { Debris-flow deposit } \\
\text { Deep levee }\end{array}$ & $\begin{array}{l}\text { Bottom of interval } \\
\text { Entire interval } \\
\text { Top of interval }\end{array}$ \\
\hline 934 & 0 & 109 & 0.70 & Channel sand & Not available \\
\hline 935 & $\begin{array}{r}0 \\
113 \\
156 \\
209 \\
276\end{array}$ & $\begin{array}{l}105 \\
156 \\
200 \\
273 \\
377\end{array}$ & $\begin{array}{l}0.70 \\
1.50 \\
0.70 \\
1.00 \\
0.70\end{array}$ & $\begin{array}{l}\text { Levee } \\
\text { Debris-flow deposit } \\
\text { Levee } \\
\text { Debris-flow deposit } \\
\text { Deep levee }\end{array}$ & $\begin{array}{l}\text { Bottom of interval } \\
\text { Entire interval } \\
\text { Not available } \\
\text { Entire interval } \\
\text { Top of interval }\end{array}$ \\
\hline 936 & $\begin{array}{r}0 \\
154 \\
294 \\
377 \\
381 \\
405.5\end{array}$ & $\begin{array}{l}150 \\
294 \\
320 \\
381 \\
405.5 \\
425\end{array}$ & $\begin{array}{l}0.70 \\
1.25 \\
0.10 \\
0.70 \\
1.50 \\
0.70\end{array}$ & $\begin{array}{l}\text { Levee } \\
\text { Debris-flow deposit } \\
\text { Deep levee } \\
\text { Deep levee } \\
\text { Debris-flow deposit } \\
\text { Deep levee }\end{array}$ & $\begin{array}{l}\text { Bottom of interval } \\
\text { Entire interval } \\
\text { Top of interval } \\
\text { Not available } \\
\text { Not available } \\
\text { Not available }\end{array}$ \\
\hline 937 & 0 & 181 & 0.70 & Levee & Not available \\
\hline 938 & 0 & 306 & 0.70 & Levee & Not available \\
\hline 939 & 0 & 98 & 0.70 & Levee & Not available \\
\hline 940 & 0 & 248 & 0.70 & Levee & Center of interval only \\
\hline 941 & $\begin{array}{r}0 \\
110\end{array}$ & $\begin{array}{r}82 \\
175\end{array}$ & $\begin{array}{l}2.00 \\
0.70\end{array}$ & $\begin{array}{l}\text { Debris-flow deposit } \\
\text { Levee }\end{array}$ & $\begin{array}{l}\text { Not available } \\
\text { Not available }\end{array}$ \\
\hline 942 & 0 & 171 & 0.70 & Levee & Not available \\
\hline 943 & 0 & 105 & 0.70 & Channel sand & Not available \\
\hline 944 & $\begin{array}{r}0 \\
192 \\
269 \\
360\end{array}$ & $\begin{array}{l}185 \\
256 \\
310 \\
378\end{array}$ & $\begin{array}{l}0.70 \\
1.25 \\
0.20 \\
0.70\end{array}$ & $\begin{array}{l}\text { Levee } \\
\text { Debris-flow deposit } \\
\text { Deep levee } \\
\text { Deep levee }\end{array}$ & $\begin{array}{l}\text { Bottom of interval } \\
\text { Entire interval } \\
\text { Entire interval } \\
\text { Not available }\end{array}$ \\
\hline 945 & 0 & 75 & 0.70 & Channel sand & Not available \\
\hline 946 & $\begin{array}{r}0 \\
55 \\
129 \\
156\end{array}$ & $\begin{array}{r}50 \\
128 \\
155 \\
273\end{array}$ & $\begin{array}{l}0.70 \\
2.25 \\
1.50 \\
2.25\end{array}$ & $\begin{array}{l}\text { Levee } \\
\text { Numerous mass flows } \\
\text { Levee } \\
\text { Numerous mass flows }\end{array}$ & $\begin{array}{l}\text { Not available } \\
\text { Bottom of interval } \\
\text { Entire interval } \\
\text { Top of interval }\end{array}$ \\
\hline
\end{tabular}

stresses are equal, and the effective stress equals the overburden pressure. If $K_{0}<1$, then the horizontal stress is less than the vertical stress, and the effective stress is less than the overburden pressure. If $K_{0}>1$, then the horizontal stress is greater than the vertical stress, and the effective stress is greater than the overburden pressure. $K_{0}$ is in the range of $0.4-0.7$ for sands and normally consolidated clays and as high as 2.5-3.0 for overconsolidated clays (Stoll, 1989). For sediments sampled on Leg 155, different $K_{0}$ values were determined for different facies through comparison of calculated and log velocities where both were available (Table 3 ). The $K_{0}$ values used elsewhere were determined through correlation to the logged sections (see discussion in next section). In general, a $K_{0}$ value of 0.7 was used for sediments thought to be in-place, normally consolidated levee and channel sediments (both near-surface and at depth). A higher $K_{0}$ value of 1-2.25 was used for debrisflow deposits to represent the apparent overconsolidated nature of these deformed sediments, and a lower $K_{0}$ value of 0.1 0.2 in the sediments underlying the debris-flow deposit to represent the apparent underconsolidated (or overpressured) nature of these sediments. The major exception to this was at Site 933, where a $K_{0}$ value of 1.5 was assigned for the uppermost deeper levee based on comparing calculated and log velocities.

5. The real part of the complex shear modulus was calculated from the effective stress and the porosity using the relationship presented by Bryan and Stoll (1988). Bryan and Stoll (1988) analyzed the results of a number of soil tests to develop a rela- 
tionship between the effective stress, the porosity, and the real part of the shear modulus. A "field factor" $(F F)$ of 2.25 within the range permitted by Bryan and Stoll (1988) was used with this relationship (see discussion in next section). This relationship assumes that the shear modulus is dependent only on effective stress and porosity. The relationship does not apply where other factors, such as gas or cementation, affect the shear modulus.

6. Values were assigned for the remaining parameters needed for the acoustic model following Stoll (1989). The near-surface log decrement, a measure of attenuation, is assumed constant at 0.1 for sediment Categories 1, 2, and 3; 0.05 is the constant for the sandier sediment Category 4 (values appropriate for silty and sandy sediments, respectively; Stoll, 1989). The log decrement is decreased as overburden is increased following Stoll (1989). A value for the bulk modulus of the skeletal frame needs to be specified that is consistent with the shear modulus. Stoll (1989) suggests that this can be done by choosing a Poisson's ratio of the skeletal frame of $0.1-0.2$ and by choosing a ratio between Young's modulus and the shear modulus between 1.0 and 1.5. For this study, values of 0.1 and 1.3, respectively, were used. The structure factor, describing the overall shape of the intergrain pores, ranges from 1 for parallel capillaries to 3.0 for capillaries with random orientation. Stoll (1989) suggests that a value of 1.25 is most appropriate for real particulate materials. Most of these parameters become more important to the model in the calculation of frequency dependent attenuation. Changing these parameters did not significantly affected the compressional-wave velocity calculations.

7. In logged holes, calculated compressional-wave velocity values were compared to the nearest velocities measured by downhole $\log$ (always nominally within $0.25 \mathrm{~m}$ ). The comparison was used to guide the selection of model parameters within the suggested range as described in the next section. The values of $K_{0}$ determined for different fan units also provide some insight into fan structure.

\section{Velocity-Porosity-Clay Relationships in Different Fan Units}

Velocity-porosity-clay relationships were studied using data collected from wireline logs. Porosity was measured using the neutron porosity tool, and porosities obtained with this tool correspond closely to porosities measured in nearby laboratory samples. Compressional-wave velocity, as described above, was measured using the LSS tool. The clay (shale) volume was calculated using a gamma-ray index modified for Tertiary clastic rocks. Qualitatively, there is good correspondence between the log calculation and grain size seen in cores (Flood, Piper, Klaus, et al., 1995), although no quantitative relation has been attempted. Shale volumes determined from the gamma-ray data, although not calibrated, can provide a good indication of the grain-size trends both within one hole as well as from site to site. The gamma-ray index is a normalized gamma-ray curve:

$$
G R_{\text {index }}=\left(C G R-C G R_{\text {min }}\right) /\left(C G R_{\max }-C G R_{\text {min }}\right)
$$

where $C G R$ (corrected gamma ray) is the measured gamma-ray minus the effect of uranium (i.e., including only the gamma-ray emission from potassium and thorium). The CGR is usually a better indicator of clay content than the total gamma-ray signal, because uranium has a complex behavior not necessarily associated with the presence of clay minerals. The minimum and maximum values were determined as the 1 and 99 percentiles of all the logging data from the Amazon Fan, being respectively 25 and 95 GAPI units. The shale volume (a proxy for clay content) was calculated with the gamma-ray index for unconsolidated Tertiary rocks, according to the Larionov formula (Dresser Atlas, 1992):

$$
V_{\text {shale }}(\%)=0.083 \cdot\left[2^{\wedge}\left(3.7 \cdot G R_{\text {index }}\right]-1.0\right)
$$

Velocity-porosity-clay relationships were studied in four different sedimentary units: older buried levees, debris-flow deposits, younger surficial levees and sand-rich deposits (the high-amplitude reflection packets [HARPs] described by Flood, Piper, Klaus, et al., 1995).

\section{RESULTS AND DISCUSSION}

\section{Comparisons Between Calculated and Log Results}

All calculated and measured velocity-porosity data points derived from core and logging data are plotted on Fig. 1. The plot shows a minimum velocity at a porosity of $70 \%-80 \%$ and a velocity increase as porosity is reduced. The log data was collected only deeper than $70-80 \mathrm{~m}$, and thus the logs did not sample sediments with porosities greater than $65 \%$ or velocities $<1.5 \mathrm{~km} / \mathrm{s}$. The log data show a greater spread in porosity for a given velocity than the index properties data show, and log porosities appear somewhat higher than index-properties porosities. The higher log porosities are because the neutron log measures all water, even that bound on clay minerals, whereas index properties measure only the water between the mineral grains. At lower porosities $(<\sim 45 \%)$, the log data show two distinct fields, with the same velocity being characteristic of both higher and lower porosity sediments. A similar trend is present in the predicted index properties data, but it is less well defined. The sediment samples from the left hand (higher velocity) trend are in general sandier than those on the right-hand trend demonstrating a control of sediment type on velocity structure. Few index properties measurements are available from sandy units because they were poorly recovered.

The compressional-wave velocity values calculated from physical properties and the compressional-wave velocity values measured by wireline logs are in good overall agreement (Fig. 2). A regression of 455 measured-calculated pairs shows a slope of 1.009, an intercept of $-25 \mathrm{~m} / \mathrm{s}$, and a correlation coefficient of 0.786 . About 14 points fall more than $1 \mathrm{~km} / \mathrm{s}$ off the correlation line. Many of these points occur in parts of holes where sediment properties change over short distances downhole. Miscorrelation of log and index-properties sample depths in such a region may result in an apparently large error.

Downcore plots of porosity, $K_{0}$, summary lithology, calculated velocity, $\log$ velocity, and the velocity of the pore waters are shown for all sites with log data in Figs 3-9. The overall match between the calculated and measured (log) velocity profiles appears quite good. The fit at Site 946 is the poorest, perhaps because sediments here are generally coarser than at other sites, and the parameters used to calculate velocity at other sites may not be appropriate for this site. In general, near-surface sediment velocities are below water velocity for about $25 \mathrm{~m}$, typical of fine-grained deep-sea sediments, and velocity in the upper $100 \mathrm{~m}$ increases with depth at a rate of $0.2 \mathrm{~km} / \mathrm{s}$ per km $\left(0.2 \mathrm{~s}^{-1}\right)$. Abrupt, sustained velocity increases occur at depth in some holes because of the presence of debris-flow deposits, and abrupt, sustained velocity decreases occur in some holes in the sediments that underlie the debris-flow deposits. There are a number of instances where thinner high log velocity values are not replicated by the calculated velocity values. This may be because the high-velocity layers represent sand layers that were not recovered or sampled, or there may be other high-velocity materials, such as hydrates, present in the sediments at some depths. Low-velocity layers in the log data may represent intervals where the borehole is large and where the log data is degraded.

There appears to be a slight tendency for the calculated compressional-wave velocity to be lower than the log compressional-wave velocity at lower velocities (Fig. 2). The tendency for the calculation to underpredict velocities in the shallower parts of the section is particularly clear at Site 940 (Fig. 7). This underprediction may result, because the authigenic iron sulfides (i.e., hydrotroilite) were found unusually deep at this site. Hydrotroilite may act to cement together 
Core data

Logging data

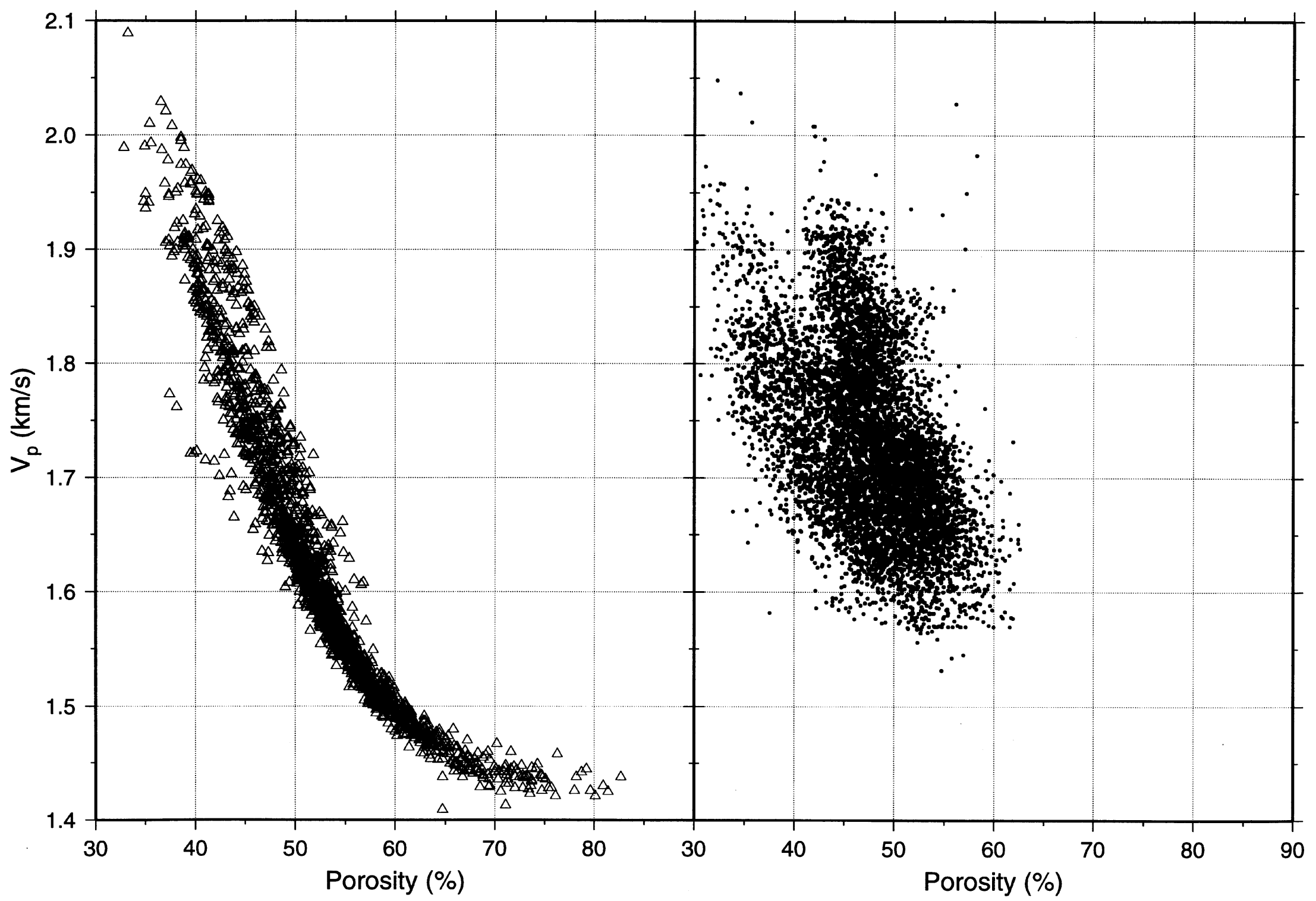

Figure 1. Cross-plot of porosity and velocity data for core data (left) and wireline logs (right). Velocity for the core data was calculated from measured shipboard porosity and grain density data, and 


\section{Amazon Fan (Leg 155) Velocity Correlation}

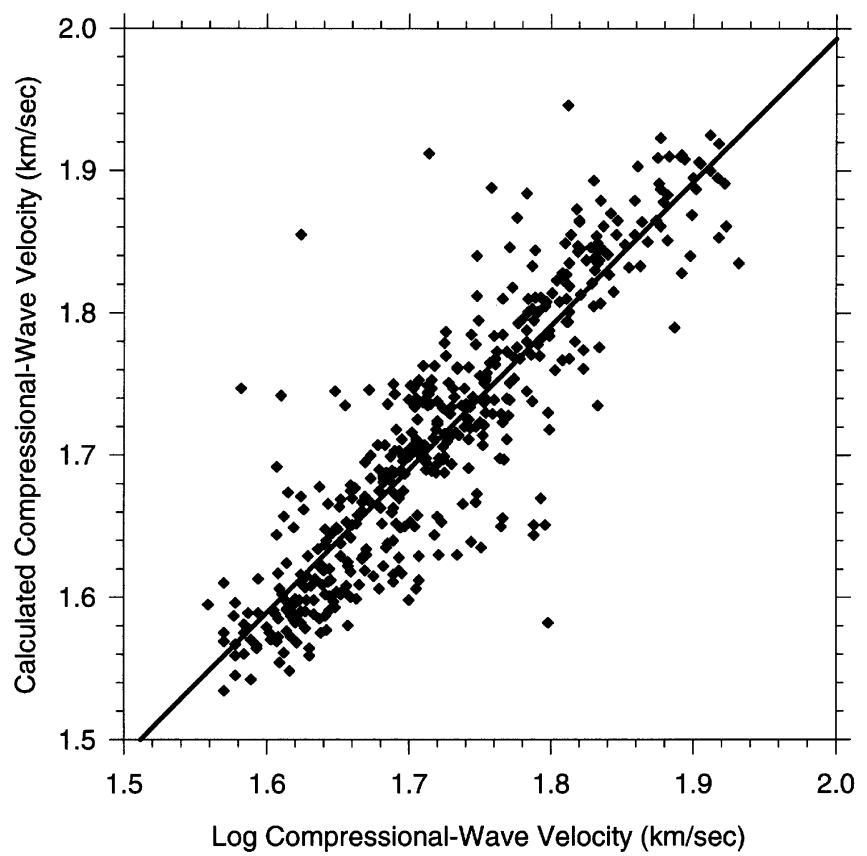

Figure 2. Cross-plot of calculated compressional-wave velocity with the velocity measured by wireline logs for the same depth in the hole. Data from all sites where log data were obtained are plotted.

the structure (see fig. 10 of Shipboard Scientific Party, 1995e), thus leading to a higher shear modulus and a higher compressional-wave velocity. We may need to modify the elastic constants used in nearsurface sediments to account for this cementation. A systematic uncertainty of $\sim 30 \mathrm{~m} / \mathrm{s}$ in velocity over a distance of $100 \mathrm{~m}$ (the approximate magnitude of the offset in Fig. 2) will lead to an uncertainty of $\sim 2 \mathrm{~m}$ in depth deeper in the profile. This is within the margin of error of the overall calculation. Some other minor inconsistencies were also observed. Some of these could also result from the presence of gas hydrates in the sediments. Two model parameters were varied within well-defined ranges to improve the correlation between calculated and measured sediment velocities: $F F$ and $K_{0}$. Both $F F$ and $K_{0}$ affect the calculation of the shear modulus. $K_{0}$ is used to determine effective stress from overburden and $F F$ is used to correct the shear modulus (calculated from porosity and effective stress) to in situ values. Increasing $F F$ and/or $K_{0}$ will result in an increased shear modulus (and an increased compressional-wave velocity) for the same overburden. Consistent values of these parameters were determined by setting $K_{0}$ at 0.7 for the apparently normally consolidated levee sediments and adjusting $F F$ to get a reasonable fit. The $F F$ value thus determined, 2.25, is at the upper end of the allowed range (1.75 to 2.25; Bryan and Stoll, 1988). $K_{0}$ values were then adjusted downcore in logged sections with different lithologic units (e.g., near-surface levee, debris-flow deposit, and deeply buried levee) to better fit the $\log$ data (Table 3 ). $K_{0}$ values appropriate to particular lithologies were then used in other depth ranges or sites were logging velocity data was not available, resulting in up to six $K_{0}$ values per site.

The $K_{0}$ values determined by this approach are particularly interesting in the deep levee deposits. Debris-flow deposits over $100 \mathrm{~m}$ thick were found on top of many of these deep levees, and shipboard analysis of logging and physical properties data suggested that the uppermost portions of some of these buried levees were underconsolidated (e.g., Shipboard Scientific Party, 1995c). At Sites 936 ( 300 mbsf; Fig. 6) and 944 ( 300 mbsf), $K_{0}$ values of $\sim 0.1$ and 0.2 were needed to match log and calculated compressional-wave velocities. This low $K_{0}$ means that the effective stress is less than what would be expected for a normally consolidated sediment; a $K_{0}$ of 0 would mean that the effective stress was half of the value for normally consolidated sediments. Using a $K_{0}$ of 0.7 instead of 0.1 would result in a calculated compressional-wave velocity that is $53 \mathrm{~m} / \mathrm{s}$ higher; a $K_{0}$ of 1.25 would result in a calculated compressional-wave velocity 88 $\mathrm{m} / \mathrm{s}$ higher than a $K_{0}$ of 0.1 .

In contrast, the $K_{0}$ value determined for the deeply buried levee at Site 933, also buried by a mass flow, is 1.5 (Fig. 4; see Shipboard Scientific Party, 1995b), suggesting that this levee crest at $\sim 170$ mbsf is actually overconsolidated. This suggests that the decrease in velocity from the debris-flow deposit to the levee is not a result of underconsolidated sediments, although there are changes in porosity and $K_{0}$ from the debris-flow deposit to the buried levee. The relatively high $K_{0}$ for the buried levee might be consistent with the debris-flow deposit being emplaced some time after the levee was deposited, or with the compaction of a sediment that had been deformed when the debris flow was deposited. Alternatively, the higher $K_{0}$ in the buried levee could indicate that sediments here are partially cemented, perhaps by hydrotroilite.

In assessing the quality of the correlation between calculated and measured values, it is important to note that the parameters used in the calculation of compressional-wave velocity were fixed or had limited ranges, either determined through measurement or through correlation to sediment descriptions or laboratory studies. The good overall agreement between calculated and measured values indicates that the Biot model as implemented by Stoll (1989) is providing a reasonable description of compressional-wave velocity in this environment, and that the relationship presented by Bryan and Stoll (1988) relating the shear modulus to effective stress and porosity appears to be an appropriate one to use for this study. We would have had to use another approach to determine the shear modulus if other factors, such as cementation or gas, had been of importance.

\section{Traveltime vs. Depth}

Revised time-depth plots are used to better correlate recovered sequences to $100-\mathrm{kHz}$ seismic profiles, and thus to better understand the processes of fan development. Time-depth plots and tables were generated for each site based on the calculated compressional-wave velocity profiles (Fig. 10; Table 4). The calculated time-depth plots for the individual sites fall along the same trend, to within $5 \mathrm{~m}$, to a sub-bottom depth of $200 \mathrm{~m}$. Deeper than $200 \mathrm{~m}$, the individual sites diverge from one another, resulting in site-to-site differences in depth to a given travel time of 10-20 m. This difference results in part from the presence and location of the high-velocity debris-flow deposit. At Site 938, where no debris-flow deposit was encountered, sediment velocities are lower than at other sites and sub-bottom depths are smaller. At Site 931, where a debris-flow deposit is deep in the section (and where there are thick high-velocity sand deposits overlying the debris-flow deposit), sediment velocities are higher than at other sites, and sub-bottom depths are larger. A time-depth relationship is therefore needed for each site to provide the best correlation between the cored sequences and the acoustic records.

The shipboard time-depth relationship used aboard Leg 155 during and after Site 931 (Fig. 10; Flood, Piper, Klaus, et al., 1995) agrees to better than $5 \mathrm{~m}$ with the calculated time-depth curves at subbottom depths $<200 \mathrm{~m}$ (traveltimes $>250 \mathrm{~ms}$ ) and with the time-depth curve calculated for Site 938 at all depths. Deeper than $200 \mathrm{~m}$ the actual depths for all sites, except Site 938, are deeper than predicted depths. At $400 \mathrm{mbsf}$ (480 ms), the error increases to $10 \mathrm{~m}$ at Site 936 and to $20 \mathrm{~m}$ at Site 931 . The time-depth curve used in the discussion of Site 930 in Flood, Piper, Klaus, et al. (1995) differs slightly from that used starting at Site 931, predicting sub-bottom depths that are 3-5 m deeper than actual throughout the sediment column. The primary geological effect of using the revised time/depth plot is that the 
Site 931 Compressional-Wave Velocity Profile
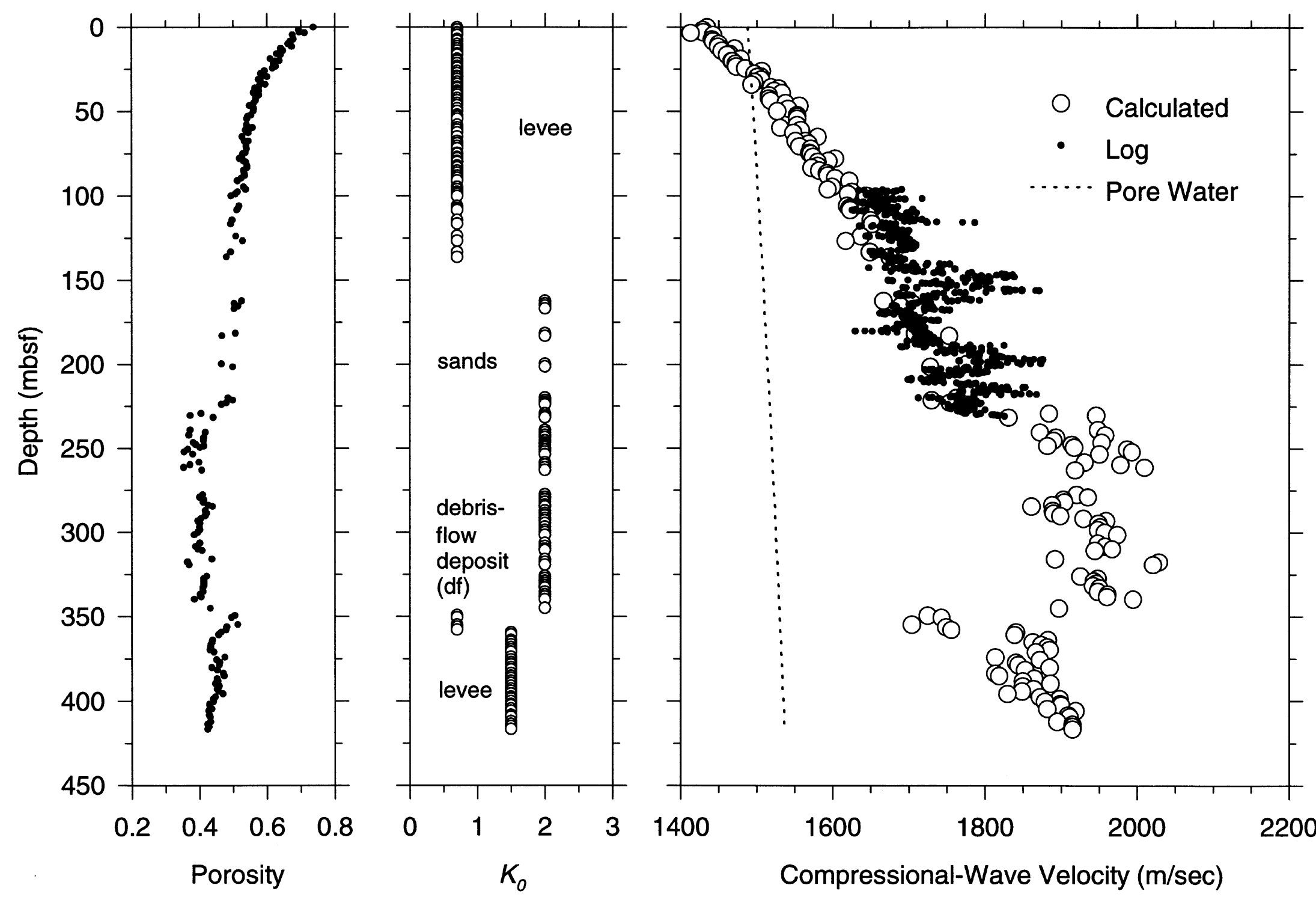

Figure 3. Downhole plots of porosity (measured on index properties samples), $K_{0}$, and calculated, log, and pore-water compressional-wave velocity at Site 931 . No velocity log data were recovered deeper than $\sim 225 \mathrm{~m}$ because of hole collapse. There is good agreement between calculated and measured velocity in the upper levee using $K_{0}=0.7$, but $K_{0}=2$ is needed to match the calculated $\log$ velocity data within the sandy unit. A thin zone of $K_{0}=0.7$ then $K_{0}=1.5$ is assigned to the deep levee. 
Site 933 Compressional-Wave Velocity Profile
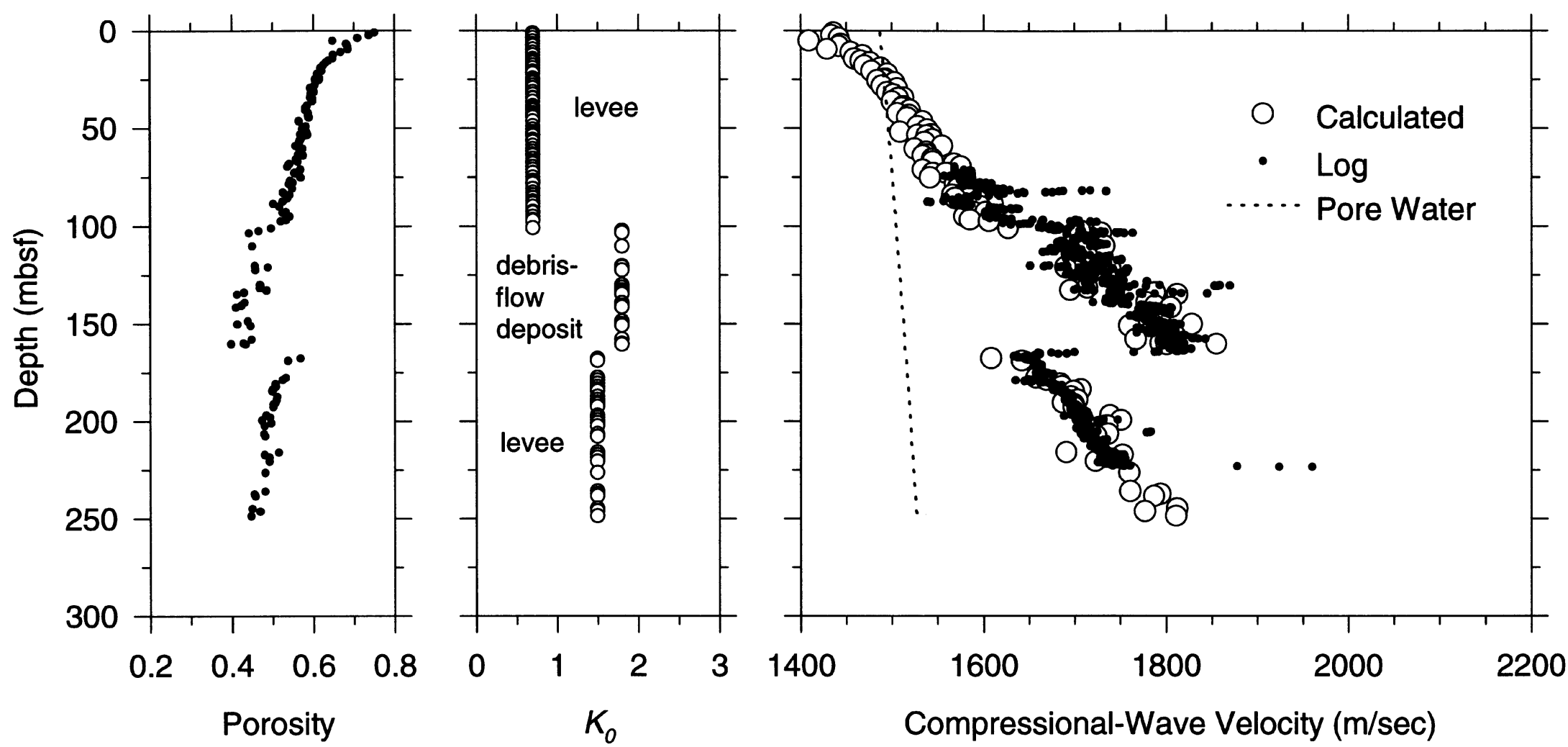

Figure 4. Downhole plots of porosity (measured on index properties samples), $K_{0}$, and calculated, log, and pore-water compressional-wave velocity at Site 933 . No velocity log data were recovered deeper than $\sim 225 \mathrm{~m}$ because of hole collapse. There is good agreement between calculated and measured velocity in the upper levee and sands using $K_{0}=0.7$, but $K_{0}=1.75$ is needed to match the $\log$ velocity data in the debris-flow deposit. Below the debris-flow deposit, $K_{0}=1.5$ is needed to match the log velocity. This high value of $K_{0}$ suggests that the sediment column here is overconsolidated. 
Site 935 Compressional-Wave Velocity Profile
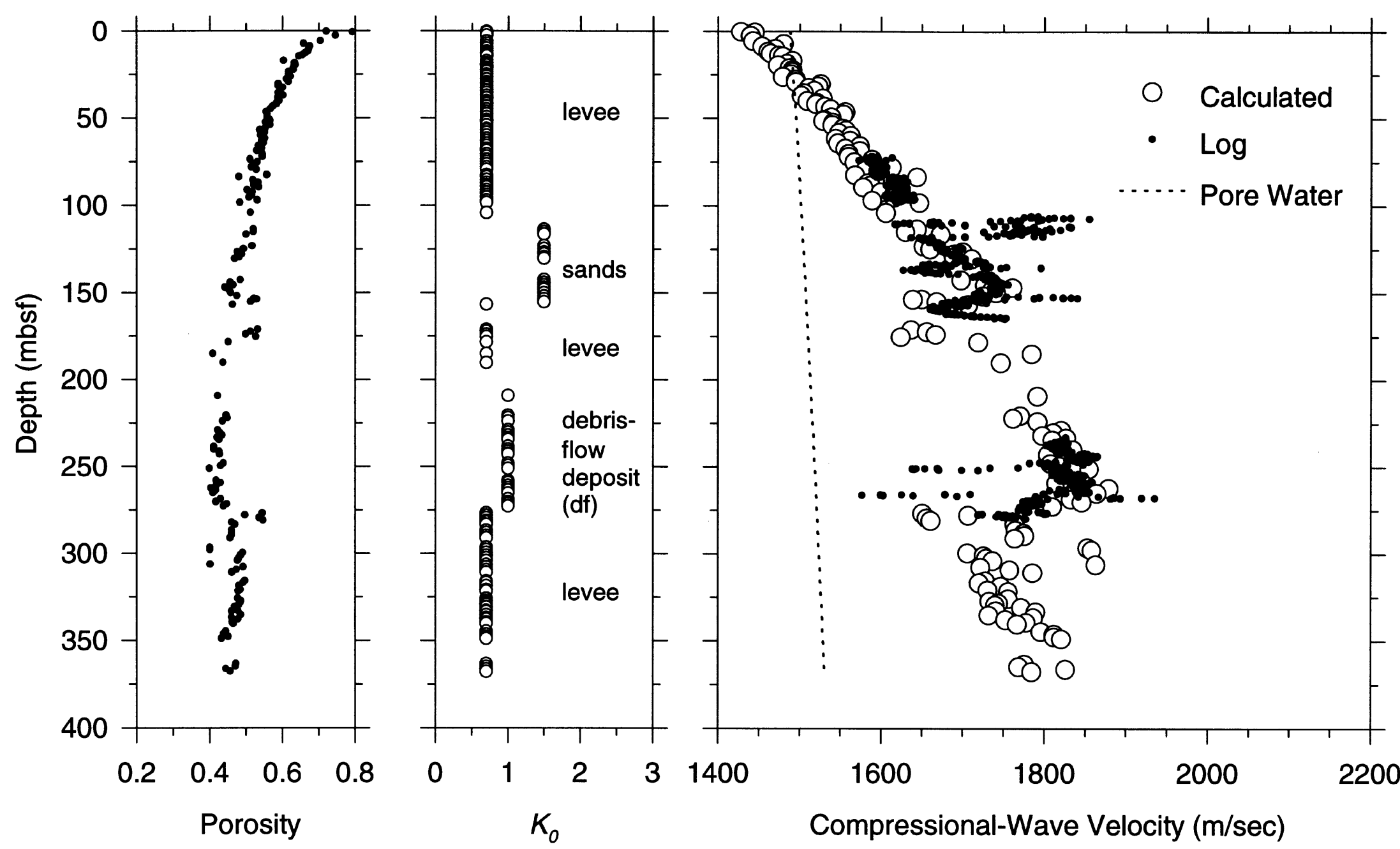

Figure 5. Downhole plots of porosity (measured on index properties samples), $K_{0}$, and calculated, log, and pore-water compressional-wave velocity at Site 935 . No velocity log data were recovered between $\sim 160$ and $225 \mathrm{~m}$ or deeper than $\sim 275 \mathrm{~m}$ because of hole collapse. There is good agreement between calculated and measured velocity in the upper levee using $K_{0}=0.7$, but $K_{0}=1.5$ is needed to match the log velocity data in the sandy unit and $K_{0}=1.0$ is needed to match the log data in the debris-flow deposit. $K_{0}=0.7$ is assigned to the buried levee. 

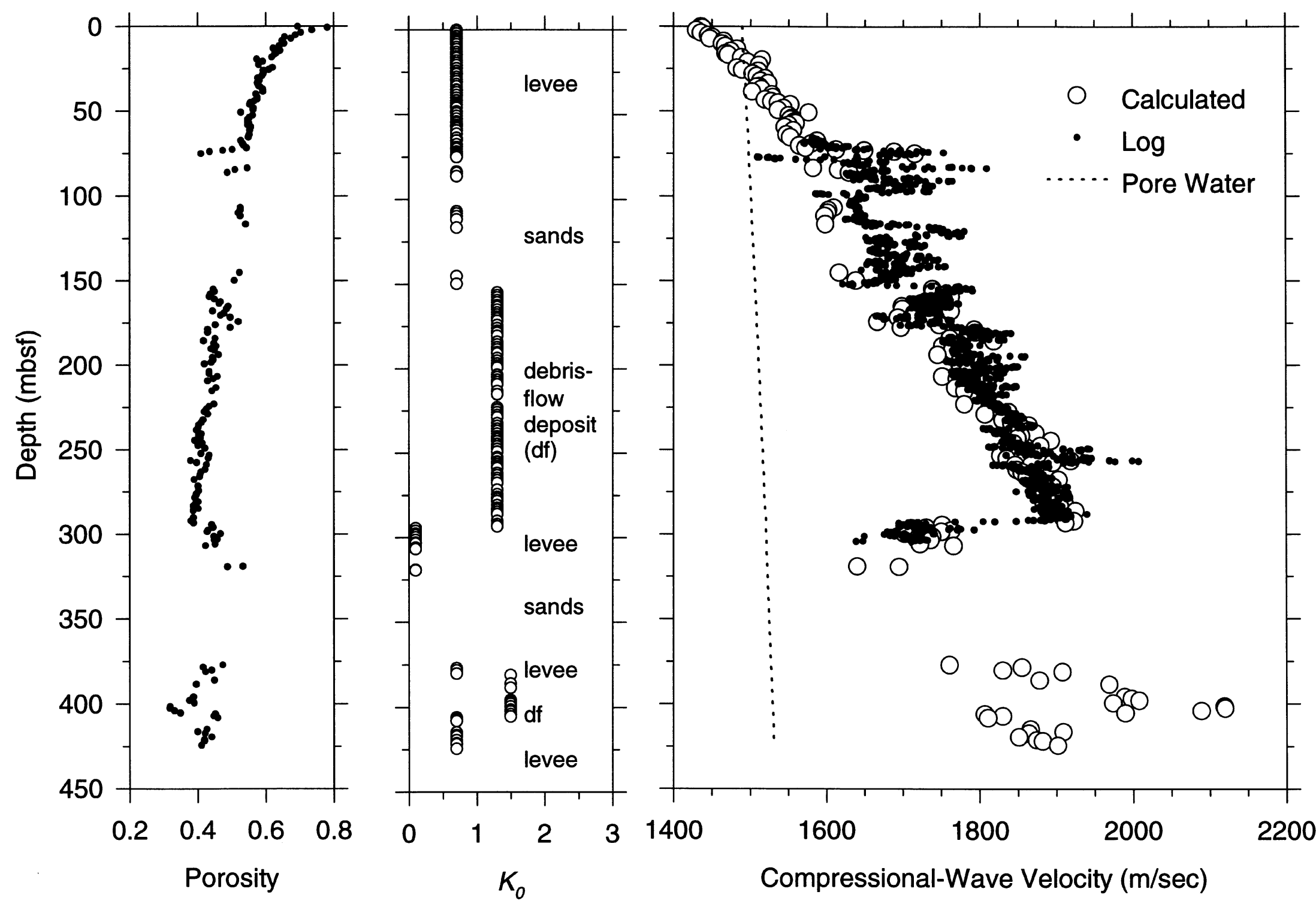

Figure 6. Downhole plots of porosity (measured on index properties samples), $K_{0}$, and calculated, log, and pore-water compressional-wave velocity at Site 936 . No velocity log data were recovered deeper than $\sim 300 \mathrm{~m}$ because of hole collapse. There is good agreement between calculated and measured velocity in the upper levee and sands using $K_{0}=0.7$, but $K_{0}=1.25$ is needed to match the log velocity data in the debris-flow deposit. Immediately below the debris-flow deposit, a $K_{0}=0.1$ is needed to match the log velocity. This low value of $K_{0}$ suggests that the sediment column here is underconsolidated. $K_{0}$ values are assigned to other layers based on data in all holes. 
Site 940 Compressional-Wave Velocity Profile
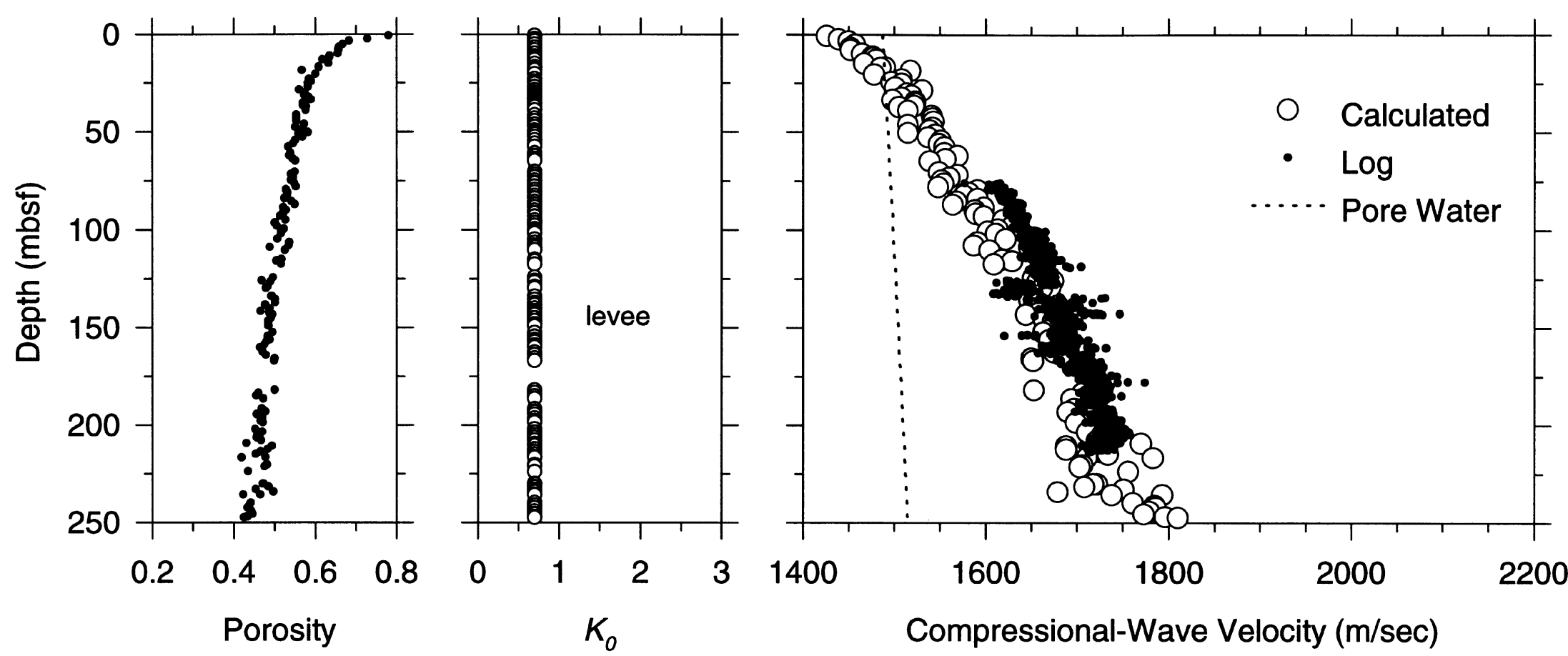

Figure 7. Downhole plots of porosity (measured on index properties samples), $K_{0}$, and calculated, log, and pore-water compressional-wave velocity at Site 940 . The acoustic model fits the measured data well at this site (except shallower than $125 \mathrm{~m}$ ) and in surficial levees at other sites using $K_{0}=0.7$. The mismatch between calculated and log velocity shallower than 125 mbsf may result from the presence of a cement (possibly iron sulfide in the form of hydrotroilite) in the sediments at this depth. The fit in this sub-bottom region was much better at other sites. 
Site 944 Compressional-Wave Velocity Profile
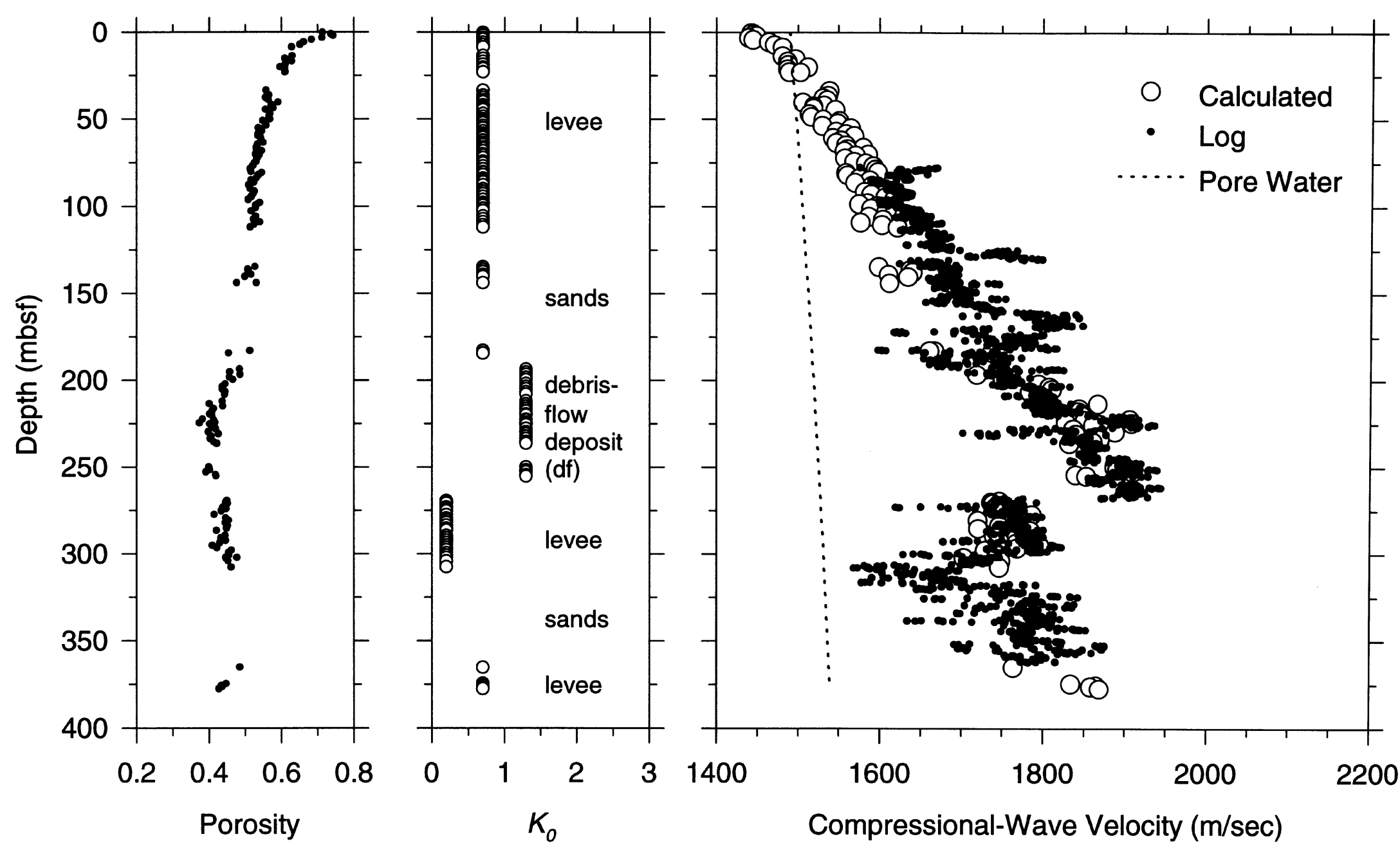

Figure 8. Downhole plots of porosity (measured on index properties samples), $K_{0}$, and calculated, log, and pore-water compressional-wave velocity at Site 940 . There is good agreement between calculated and measured velocity in the upper levee and sands using $K_{0}=0.7$, but $K_{0}=1.25$ is needed to match the log velocity data in the debris-flow deposit. Immediately below the debrisflow deposit, a $K_{0}=0.2$ is needed to match the log velocity. This low value of $K_{0}$ suggests that the sediment column here is underconsolidated. $K_{0}$ values are assigned to other layers based on data in all holes. 
Site 946 Compressional-Wave Velocity Profile
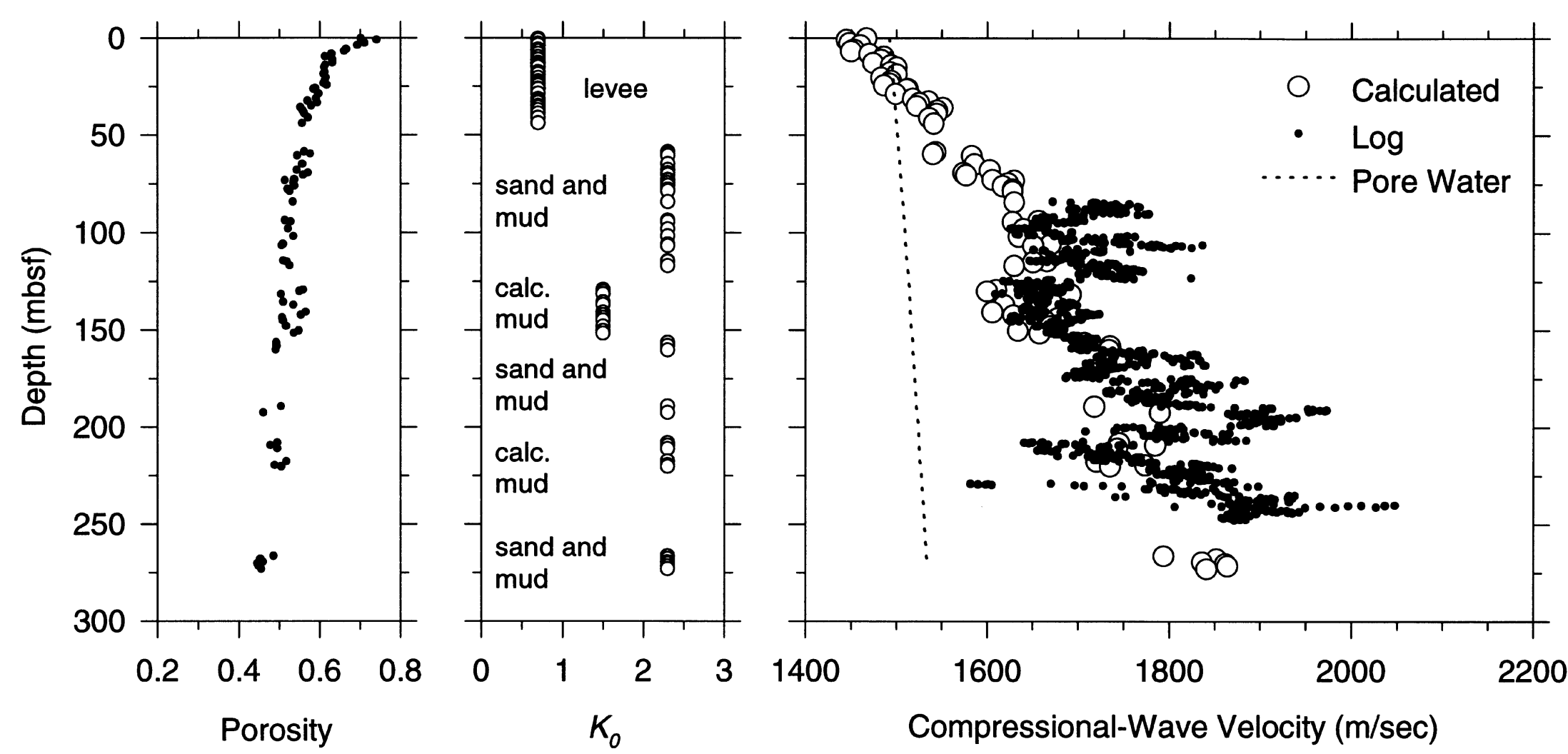

Figure 9. Downhole plots of porosity (measured on index properties samples), $K_{0}$, and calculated, log, and pore-water compressional-wave velocity at Site $946 . K_{0}$ values assigned to match the log velocity data are generally lower (as low as 1.5 ) in the calcareous mud units than in the sand and mud mass-flow units (2.25); however, the fit between the calculated and log velocity is poorer at this site than at the other sites. $K_{0}$ values are assigned to other layers based on data in all holes. 


\section{Amazon Fan Time-Depth Plot}

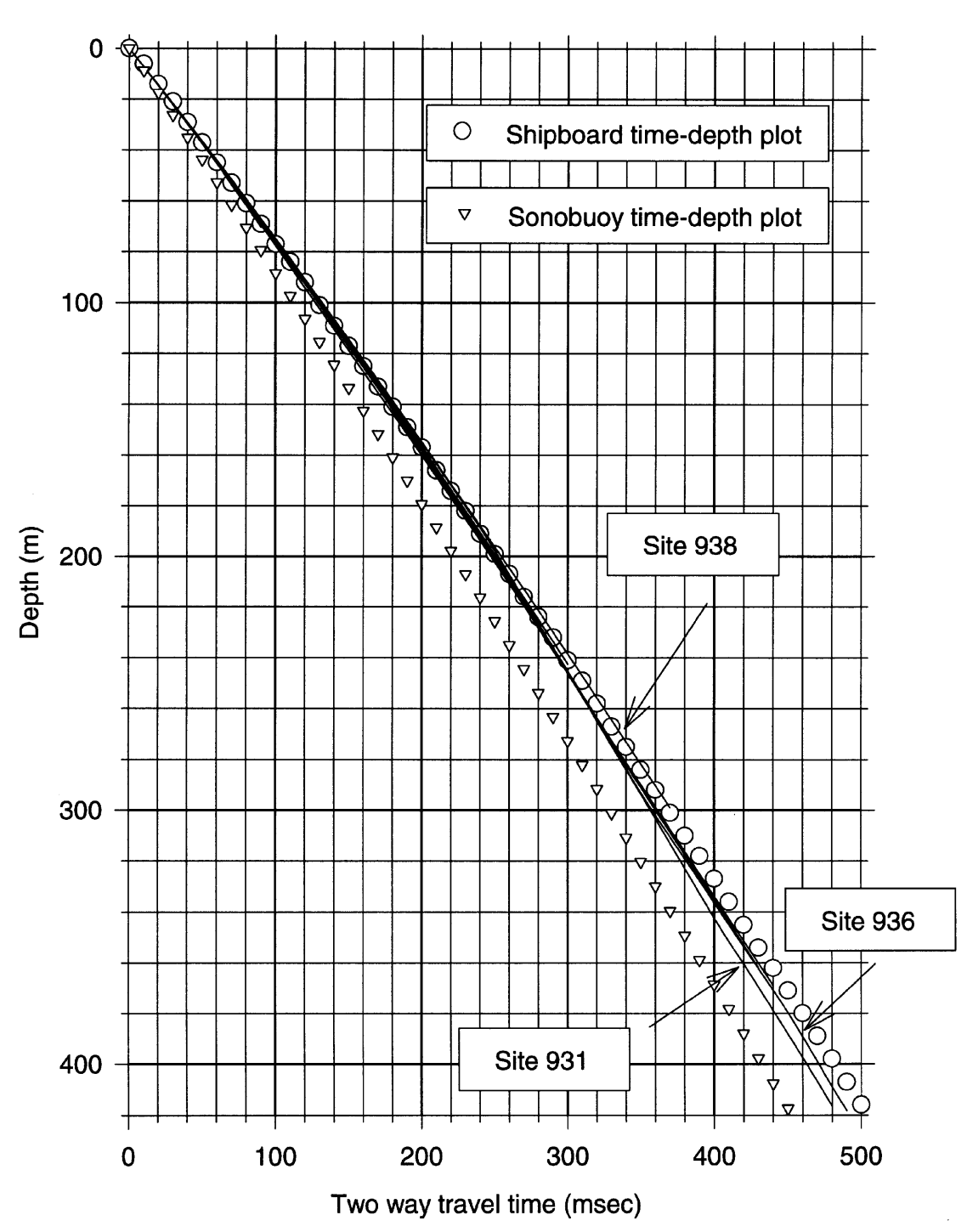

Figure 10. Time-depth plot for all Leg 155 sites. Also shown are plots of the relationship used aboard Leg 155 to calculate sub-bottom depths and the relationship determined from the analysis of sonobuoy data from the region.

prominent seismic reflection at the base of the debris-flow deposit correlates more precisely with the base of the debris-flow deposit observed in the cores. However, more detailed correlations between acoustic profiles and the cored sequences will be possible because of these the improved time-depth relationships.

The sediment velocities determined during this study are somewhat lower than those suggested by Houtz (1977) based on sonobuoy measurements from the Amazon Fan (see also Shipboard Scientific Party, 1995a). As a result, sub-bottom depths calculated using the Houtz (1977) time-depth relationship are 10\%-15\% deeper than those determined using the revised relationship. This may in part reflect the difficulty in determining the velocity of near-surface sediment layers using sonobuoy wide-angle reflection and refraction techniques that primarily measure velocities deeper in the sediment column. Also, sonobuoys are primarily measuring velocity parallel to bedding, whereas we are interested here in velocity perpendicular to bedding.

\section{Velocity-Porosity-Clay Relationships}

Yin (1993) devised a series of experiments to determine the effects of clay content and compaction on the velocity, permeability, and porosity of shaley sands by creating sand-clay mixtures and analyzing their velocity and porosity as they are compacted. As clay content was increased in laboratory samples from zero (pure sand), porosity decreased as the space between the sand grains was filled with clay, although the clay does not bear any of the stresses applied to the sample (a grain-supported structure, also called an isostrain condition because both the sand grains and clay minerals are subjected to the same strains). The "critical" clay content occurs when the maximum velocity and the minimum porosity are reached. As clay content increases beyond the critical value, sand grains lose direct contact, and porosity increases because porous clay grains push the denser sand grains apart. Both clay and sand particles may equally bear stresses applied on the sample (a matrix supported structure, also called an isostress condition because both sand grains and clay minerals now have the same stresses). The velocity of the sediment sample also changes as the clay content is increased. Below the critical value, the clay goes into the pore space and stiffens the structure resulting in an increasing velocity as porosity decreases with clay content (Fig. 11, left side). As clay content increases beyond the critical value, the clay particles will push the sand lattice apart, somewhat reducing the strength of the sediment. Under these conditions, velocity will decrease and porosity will increase with increased clay content (Fig. 11, 
Table 4. Depth at each site as a function of traveltime.

\begin{tabular}{|c|c|c|c|c|c|c|c|c|c|c|c|c|c|c|c|c|c|}
\hline \multirow{2}{*}{$\begin{array}{l}\text { Traveltime } \\
\quad(\mathrm{ms})\end{array}$} & \multicolumn{17}{|c|}{ Site depth (mbsf) } \\
\hline & 930 & 931 & 932 & 933 & 934 & 935 & 936 & 937 & 938 & 939 & 940 & 941 & 942 & 943 & 944 & 945 & 946 \\
\hline 0 & 0.0 & 0.0 & 0.0 & 0.0 & 0.0 & 0.0 & 0.0 & 0.0 & 0.0 & 0.0 & 0.0 & 0.0 & 0.0 & 0.0 & 0.0 & 0.0 & 0.0 \\
\hline 10 & 7.2 & 7.2 & 7.2 & 7.2 & 7.3 & 7.2 & 7.2 & 7.2 & 7.3 & 7.3 & 7.2 & 7.2 & 7.2 & 7.3 & 7.3 & 7.3 & 7.3 \\
\hline 20 & 14.5 & 14.4 & 14.5 & 14.4 & 14.6 & 14.6 & 14.5 & 14.5 & 14.5 & 14.7 & 14.6 & 14.6 & 14.4 & 14.8 & 14.7 & 14.6 & 14.7 \\
\hline 30 & 21.8 & 21.8 & 21.8 & 21.8 & 22.1 & 22.0 & 22.0 & 21.9 & 21.8 & 22.1 & 22.0 & 22.1 & 21.7 & 22.3 & 22.1 & 22.1 & 22.1 \\
\hline 40 & 29.3 & 29.2 & 29.3 & 29.3 & 29.7 & 29.4 & 29.5 & 29.4 & 29.3 & 29.6 & 29.6 & 29.8 & 29.0 & 29.8 & 29.7 & 29.5 & 29.6 \\
\hline 50 & 36.7 & 36.7 & 36.8 & 36.8 & 37.3 & 37.0 & 37.1 & 36.9 & 36.8 & 37.2 & 37.1 & 37.5 & 36.5 & 37.4 & 37.4 & 37.3 & 37.3 \\
\hline 60 & 44.2 & 44.4 & 44.3 & 44.4 & 44.9 & 44.6 & 44.7 & 44.6 & 44.3 & 44.9 & 44.8 & 45.4 & 44.1 & 45.2 & 45.0 & 45.4 & 45.0 \\
\hline 70 & 51.7 & 52.1 & 52.0 & 52.0 & 52.7 & 52.3 & 52.4 & 52.2 & 51.9 & 52.6 & 52.5 & 53.2 & 51.7 & 53.0 & 52.6 & 53.9 & 52.7 \\
\hline 80 & 59.3 & 59.8 & 59.7 & 59.7 & 60.6 & 60.1 & 60.2 & 60.0 & 59.6 & 60.3 & 60.2 & 61.2 & 59.5 & 60.8 & 60.4 & 62.0 & 60.4 \\
\hline 90 & 67.1 & 67.6 & 67.4 & 67.4 & 68.5 & 67.8 & 68.0 & 67.8 & 67.3 & 68.1 & 68.0 & 69.4 & 67.1 & 68.7 & 68.2 & 70.3 & 68.3 \\
\hline 100 & 74.9 & 75.4 & 75.3 & 75.2 & 76.5 & 75.7 & 76.0 & 75.7 & 75.0 & 75.9 & 75.7 & 77.7 & 74.8 & 76.7 & 76.0 & & 76.4 \\
\hline 110 & 82.8 & 83.4 & 83.2 & 83.0 & 84.4 & 83.6 & 84.2 & 83.6 & 82.8 & 83.8 & 83.6 & 85.9 & 82.7 & 84.8 & 83.9 & & 84.5 \\
\hline 120 & 90.7 & 91.3 & 91.1 & 90.9 & 92.4 & 91.6 & 92.3 & 91.6 & 90.7 & 91.7 & 91.5 & 94.2 & 90.7 & 92.7 & 91.9 & & 92.7 \\
\hline 130 & 98.7 & 99.4 & 99.1 & 98.9 & 100.5 & 99.7 & 100.4 & 99.6 & 98.6 & & 99.6 & 102.4 & 98.7 & 100.8 & 99.9 & & 100.9 \\
\hline 140 & 106.7 & 107.5 & 107.1 & 107.4 & & 107.8 & 108.5 & 107.7 & 106.6 & & 107.6 & 110.6 & 106.8 & & 107.9 & & 109.2 \\
\hline 150 & 114.7 & 115.7 & 115.3 & 116.0 & & 116.0 & 116.5 & 115.7 & 114.5 & & 115.7 & 118.9 & 114.8 & & 115.9 & & 117.4 \\
\hline 160 & 122.8 & 123.9 & 123.4 & 124.7 & & 124.3 & 124.5 & 123.8 & 122.5 & & 123.8 & 127.2 & 122.9 & & 123.9 & & 125.5 \\
\hline 170 & 131.0 & 132.1 & 131.6 & 133.3 & & 132.7 & 132.6 & 132.0 & 130.5 & & 132.1 & 135.4 & 130.9 & & 132.0 & & 133.7 \\
\hline 180 & 139.0 & 140.4 & 139.9 & 142.2 & & 141.3 & 140.6 & 140.3 & 138.5 & & 140.4 & 143.6 & 139.0 & & 140.1 & & 141.9 \\
\hline 190 & 147.1 & 148.8 & 148.2 & 151.2 & & 149.9 & 148.7 & 148.7 & 146.7 & & 148.7 & 151.9 & 147.1 & & 148.3 & & 150.2 \\
\hline 200 & 155.3 & 157.1 & 156.6 & 160.0 & & 158.3 & 157.2 & 157.1 & 154.9 & & 157.1 & 160.2 & 155.3 & & 156.7 & & 158.6 \\
\hline 210 & 163.5 & 165.5 & 165.2 & 168.5 & & 166.7 & 165.8 & 165.5 & 163.1 & & 165.5 & 168.6 & 163.5 & & 165.1 & & 167.3 \\
\hline 220 & 171.8 & 174.0 & & 176.8 & & 175.0 & 174.4 & 174.0 & 171.4 & & 173.8 & & & & 173.5 & & 175.9 \\
\hline 230 & 180.2 & 182.6 & & 185.2 & & 183.6 & 183.1 & & 179.6 & & 182.1 & & & & 181.9 & & 184.5 \\
\hline 240 & 188.6 & 191.4 & & 193.7 & & 192.4 & 192.0 & & 187.9 & & 190.5 & & & & 190.5 & & 193.2 \\
\hline 250 & 197.7 & 200.2 & & 202.3 & & 201.3 & 200.9 & & 196.2 & & 199.1 & & & & 199.2 & & 202.1 \\
\hline 260 & 207.2 & 209.0 & & 210.9 & & 210.1 & 209.8 & & 204.6 & & 207.7 & & & & 208.1 & & 210.9 \\
\hline 270 & 216.9 & 217.7 & & 219.5 & & 219.0 & 218.7 & & 213.0 & & 216.3 & & & & 217.2 & & 219.6 \\
\hline 280 & 226.5 & 226.6 & & 228.2 & & 228.0 & 227.7 & & 221.5 & & 225.0 & & & & 226.5 & & 228.4 \\
\hline 290 & 235.9 & 235.9 & & 237.0 & & 237.1 & 236.9 & & 230.0 & & 233.6 & & & & 235.8 & & 237.2 \\
\hline 300 & & 245.4 & & 246.0 & & 246.1 & 246.2 & & 238.5 & & 242.4 & & & & 245.1 & & 246.0 \\
\hline 310 & & 255.2 & & & & 255.3 & 255.4 & & 247.1 & & & & & & 254.5 & & 254.9 \\
\hline 320 & & 264.9 & & & & 264.5 & 264.7 & & 255.8 & & & & & & 263.5 & & 263.7 \\
\hline 330 & & 274.5 & & & & 273.7 & 274.2 & & 264.4 & & & & & & 272.4 & & 272.8 \\
\hline 340 & & 284.1 & & & & 282.2 & 283.7 & & 273.1 & & & & & & 281.2 & & \\
\hline 350 & & 293.6 & & & & 291.0 & 293.2 & & 281.7 & & & & & & 289.9 & & \\
\hline 360 & & 303.3 & & & & 300.0 & 302.0 & & 290.3 & & & & & & 298.7 & & \\
\hline 370 & & 313.1 & & & & 308.8 & 310.6 & & 299.0 & & & & & & 307.5 & & \\
\hline 380 & & 322.9 & & & & 317.6 & 319.1 & & & & & & & & 316.2 & & \\
\hline 390 & & 332.7 & & & & 326.3 & 327.7 & & & & & & & & 325.0 & & \\
\hline 400 & & 342.4 & & & & 335.1 & 336.4 & & & & & & & & 333.8 & & \\
\hline 410 & & 351.6 & & & & 343.9 & 345.0 & & & & & & & & 342.6 & & \\
\hline 420 & & 360.4 & & & & 352.9 & 353.6 & & & & & & & & 351.3 & & \\
\hline 430 & & 369.7 & & & & 361.9 & 362.3 & & & & & & & & 360.1 & & \\
\hline 440 & & 378.9 & & & & & 370.9 & & & & & & & & 369.0 & & \\
\hline 450 & & 388.2 & & & & & 379.7 & & & & & & & & & & \\
\hline 460 & & 397.5 & & & & & 389.2 & & & & & & & & & & \\
\hline 470 & & 406.9 & & & & & 399.1 & & & & & & & & & & \\
\hline 480 & & 416.5 & & & & & 409.0 & & & & & & & & & & \\
\hline 490 & & & & & & & 418.3 & & & & & & & & & & \\
\hline
\end{tabular}

right side). The value of the critical clay content will be different for different natural sediments depending on, among other things, sediment grain size and any cementation or lithification. Velocity and porosity are inversely correlated for both the grain-supported and matrix-supported cases, thus the two cases may plot along similar lines on a velocity-porosity plot.

When the velocity and porosity are plotted against shale volume in the four different sedimentary units (older buried levees, debrisflow deposits, younger surficial levees, and sand-rich deposits), some trends emerge (Fig. 12). There is significant scatter in these plots that might be expected because all of these broadly defined sedimentary units contain a wide range of sediment sizes and have different ages and consolidation histories. However, for the younger surficial levees and the sand-rich deposits, there appears to be a trend of decreasing velocity and increasing porosity as shale volume increases. This is consistent with these sediments being in an isostress condition, where clay matrix and framework grains together bear the overburden stress. For the older buried levees and the debris-flow deposits, there appears to be a trend of increasing velocity and decreasing porosity as shale volume increases. This is consistent with these sediments being in an isostrain condition, where the framework grains play more of a role in supporting the overburden stress than does the clay matrix. The change from a matrix-supported structure shallower in the section to a grain-supported structure deeper in the section may have occurred as a result of overburden, or it may have occurred during deformation (e.g., in the debris-flow deposits).
In comparing these results with those of the velocity modeling, we note that the normally consolidated surficial levee and channel sediments $\left(K_{0}=0.7\right)$ appear to be in the matrix-supported or isostress category, and the overconsolidated debris-flow deposits $\left(K_{0}\right.$ of $\left.1-2.25\right)$ appear to be in the grain-supported or isostrain category. Deep levee deposits (apparently in an overall isostrain condition) had both low and high $K_{0}$ values, indicating a range of consolidation with respect to overburden; however, the change from a matrix-supported structure to a grain-supported structure depends more on the degree of consolidation (as well as lithology and cementation) than on the subbottom depth. More detailed analysis of these data will be needed to better determine the relationships between lithology, consolidation, and acoustic properties for these sediments.

\section{CONCLUSIONS}

Compressional-wave velocity is one of several parameters important for describing the mechanical state of marine sediments. For the Amazon Fan, we can successfully use the approach of Stoll (1989) to predict sediment compressional-wave velocity from measured void ratio, or porosity, and depth of burial, although additional information is needed to determine whether the sediment is overconsolidated, normally consolidated, or undercosolidated. Comparison of calculated velocities with those measured by wireline logs suggests that debris-flow deposits are overconsolidated, whereas near-surface levees 


\section{grain-supported structure (isostrain)}
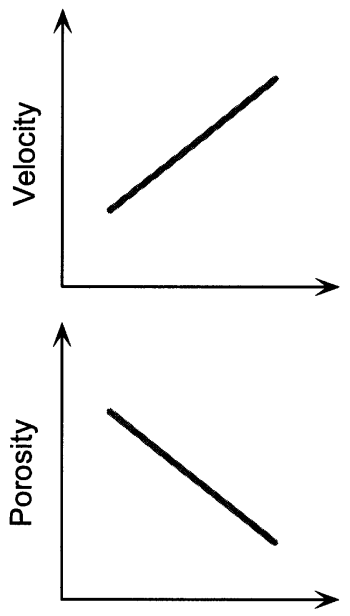

Clay Content matrix-supported structure (isostress)
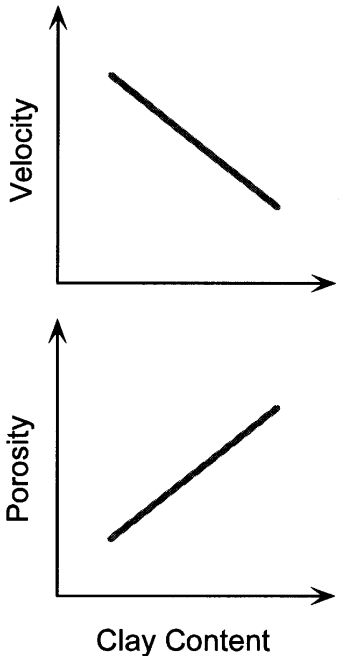

Figure 11. Theoretical relationships between compressional-wave velocity and clay volume and between porosity and clay volume for grain-supported structures (isostrain condition, left) and matrix-supported structures (isostress condition, right; after Yin, 1993). Velocity and porosity are negatively correlated in each regime, so that these regimes might not be distinguishable on a velocity-porosity plot.

and sands are normally consolidated. Deeper levee deposits can be underconsolidated (where they lie beneath relatively recent debrisflow deposits that may restrict drainage), normally consolidated, and overconsolidated (where they lie beneath a possibly older debrisflow deposit). The mechanical state of sediments that were not logged can be determined through comparison with logged sediment units of similar lithology and age.

Revised time-depth relationships were determined for all Leg 155 sites (Fig. 10; Table 4). These new relationships are similar to those used aboard ship during Leg 155 for sub-bottom depths <200 m, but diverge from previous relationships, and from one another, at deeper depths depending on the existence and location of high-velocity debris-flow deposits. Sub-bottom depths determined aboard ship for deeper seismic reflections (Flood, Piper, Klaus, et al., 1995) can be $10-20 \mathrm{~m}$ too shallow. The revised time-depth relationships will allow for more precise correlations between cores and seismic profiles.

Evaluation of the relationships between velocity and clay volume and between porosity and clay volume (determined from log data) suggests that sediments in the upper layers of the fan (surficial levees and associated sandy deposits) are in a matrix-supported or isostress condition (Yin, 1993; Yin et al., 1993), thus the stress of the overlying sediments is borne by the framework grains and the matrix grains. The debris-flow deposits and the deep levees are in a grain-supported or isostrain condition, thus the stress of the overlying sediments is born primarily by the framework grains. In both instances, some of the overburden stress can also be borne by any excess pore pressure. The transition between isostress and isostrain will depend on many factors, including sediment structure, lithology, degree of lithification or cementation (including by gas hydrates or iron sulfides), and the sedimentation and overburden history. A knowledge of whether a sediment exhibits isostress or isostrain behavior may help to determine the elastic modulii of the sediments (Yin, 1993; Yin et al., 1993).

Additional studies of Amazon Fan sediments need to better resolve the acoustic structure of individual fan units to better constrain sediment processes and depositional history. We also need to continue to develop methods for extrapolating the results of our studies in

logged boreholes to unlogged boreholes and from sampled sediments to unsampled sediments.

\section{ACKNOWLEDGMENTS}

This research was supported by the USSSP program, supported by NSF, in awards to RDF (155-20848B) and CP (155-20878B). The manuscript benefited from reviews by R.D. Stoll, R.H. Wilkens, and R.D. Larter. We also gratefully acknowledge the physical properties team on Leg 155 whose efforts resulted in our data set.

\section{REFERENCES}

Bryan, G.M., and Stoll, R.D., 1988. The dynamic shear modulus of marine sediments. J. Acoust. Soc. Am., 83:2159-2164.

Bryant, W.R., Hottman, W., and Trabant, P., 1975. Permiability of unconsolidated and consolidated marine sediments, Gulf of Mexico. Mar. Geotechnol., 1:1-14.

Carlson, R.L., Gangi, A.F., and Snow, K.R., 1986. Empirical reflection traveltime versus depth functions for the deep-sea sediment column. J. Geophys. Res., 91:8249-8266.

Dresser Atlas, 1992. Introduction to Wireline Log Analysis: Houston, TX (Western Atlas International).

Flood, R.D., Piper, D.J.W., Klaus, A., et al., 1995. Proc. ODP, Init. Repts., 155: College Station, TX (Ocean Drilling Program).

Hamilton, E.L., 1980. Geoacoustic modeling of the seafloor. J. Acoust. Soc. Am., 68:1313-1340.

Hamilton, E.L., and Bachman, R.T., 1982. Sound velocity and related properties of marine sediments. J. Acoust. Soc. Am., 72:1891-1904.

Houtz, R.E., 1977. Sound velocity characteristics of sediment from eastern South American margin. Geol. Soc. Am. Bull., 88:720-722.

Jarrard, R.D., Dadey, K.A., and Busch, W.H., 1989. Velocity and density of sediments of Eirik Ridge, Labrador Sea: control by porosity and mineralogy. In Srivastava, S.P., Arthur, M.A., Clement, B., et al., Proc. ODP, Sci. Results, 105: College Station, TX (Ocean Drilling Program), 811-835.

Jarrard, R.D., Jackson, P.D., Kasschau, M., and Ladd, J.W., 1993. Velocity and density of carbonate-rich sediments from northeastern Australian margin: integration of core and log data. In McKenzie, J.A., Davies, P.J., Palmer-Julson, A., et al., Proc. ODP, Sci. Results, 133: College Station, TX (Ocean Drilling Program), 633-647.

Shipboard Scientific Party, 1995a. Explanatory notes. In Flood, R.D., Piper, D.J.W., Klaus, A., et al., Proc. ODP, Init. Repts., 155: College Station, TX (Ocean Drilling Program), 47-81.

1995b. Site 933. In Flood, R.D., Piper, D.J.W., Klaus, A., et al., Proc. ODP, Init. Repts., 155: College Station, TX (Ocean Drilling Program), 201-239.

, 1995c. Site 936. In Flood, R.D., Piper, D.J.W., Klaus, A., et al., Proc. ODP, Init. Repts., 155: College Station, TX (Ocean Drilling Program), 321-382.

, 1995d. Site 938. In Flood, R.D., Piper, D.J.W., Klaus, A., et al., Proc. ODP, Init. Repts., 155: College Station, TX (Ocean Drilling Program), 409-436.

, 1995e. Site 939. In Flood, R.D., Piper, D.J.W., Klaus, A., et al., Proc. ODP, Init. Repts., 155: College Station, TX (Ocean Drilling Program), 437-461.]

1995f. Site 944. In Flood, R.D., Piper, D.J.W., Klaus, A., et al., Proc. ODP, Init. Repts., 155: College Station, TX (Ocean Drilling Program), 591-633.

Stoll, R.D., 1989. Sediment Acoustics: New York (Springer-Verlag), Lecture Notes in Earth Sciences, 26.

Wyllie, M.R.J., Gregory, A.R., and Gardner, L.W., 1956. Elastic wave velocities in heterogeneous and porous media. Geophysics, 21:41-70.

Yin, H., 1993. Acoustic velocity and attenuation of rocks: isotropy, intrinsic anisotropy, stress-induced anisotropy [Ph.D. thesis]. Stanford Univ.

Yin, H., Nur, A., and Mavko, G., 1993. Critical porosity: a physical boundary in poroelasticity. Int. J. Rock Mech. Min. Sci. Geomech. Abstr., 30:805808 .

Date of initial receipt: 4 December 1995

Date of acceptance: 17 May 1996

Ms 155SR-232 


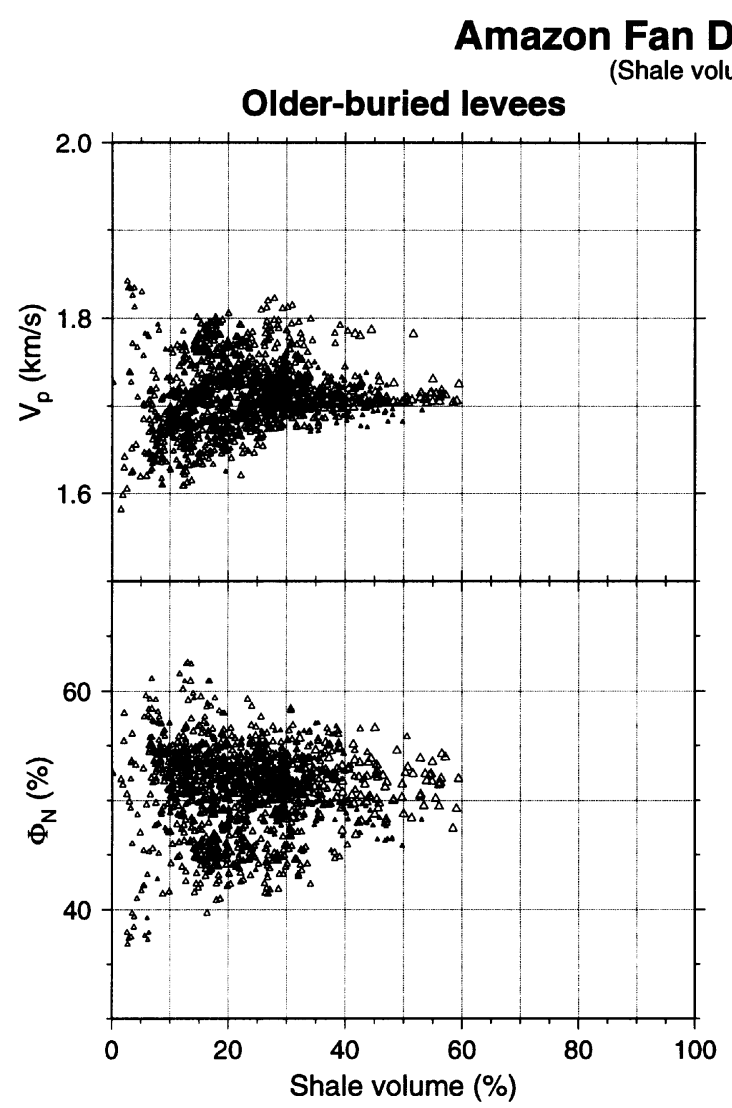

\section{epositional Units}

Shale volume from CGR)
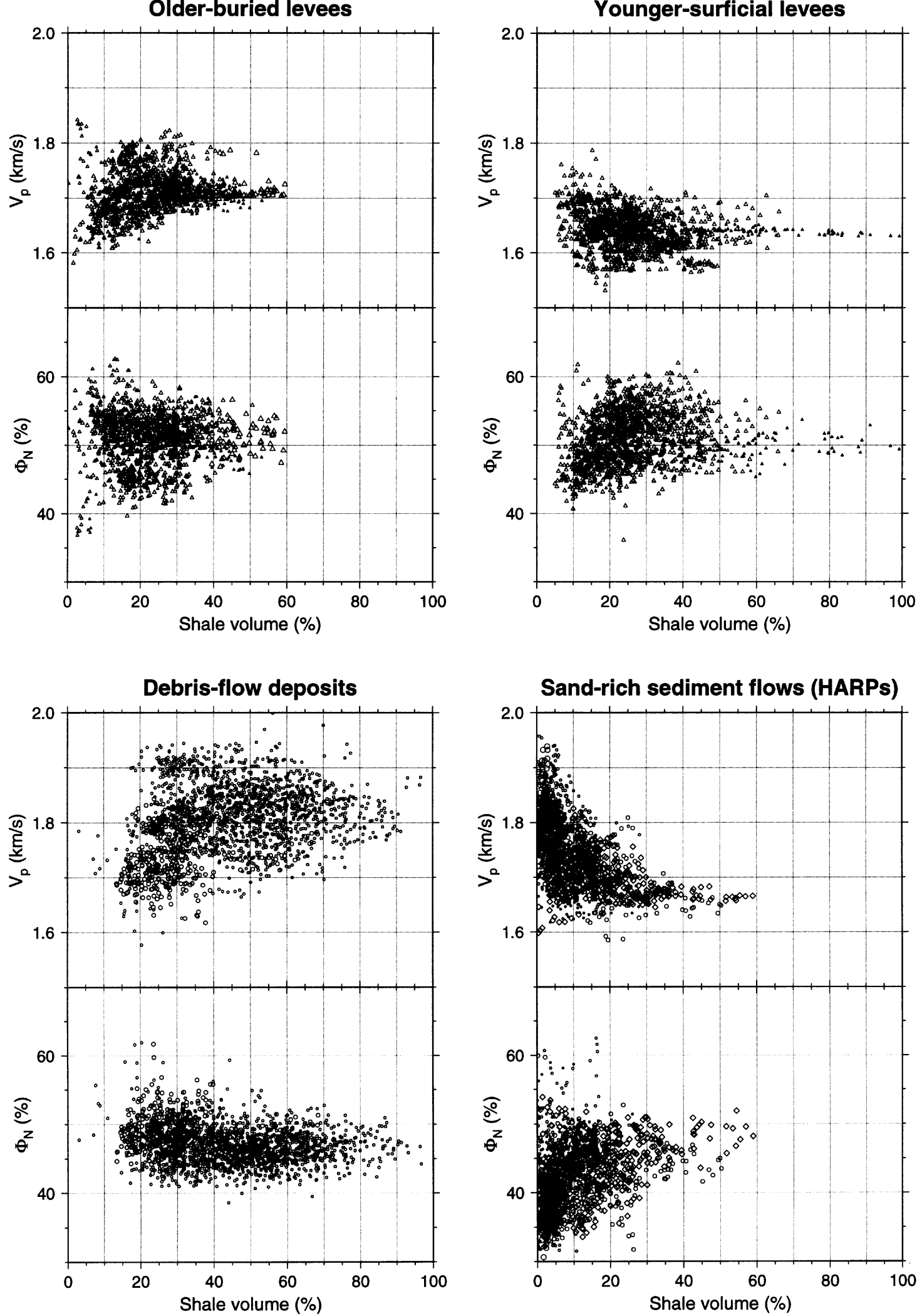

Figure 12. Relationships between velocity, porosity, and clay content derived from wireline logs for four depositional units. Older buried levees and debris-flow deposits appear to show a grain-supported structure, whereas younger surficial levees and sand-rich sediment flows appear to show a matrix-supported structure. ( $V_{p}=$ compressional-wave velocity; $\Phi_{\mathrm{N}}=$ porosity). 